NBER WORKING PAPER SERIES

\title{
WHERE DID BRITISH FOREIGN CAPITAL GO? FUNDAMENTALS, FAILURES AND THE LUCAS PARADOX 1870-1913
}

Michael A. Clemens

Jeffrey G. Williamson

Working Paper 8028

http://www.nber.org/papers/w8028

\author{
NATIONAL BUREAU OF ECONOMIC RESEARCH \\ 1050 Massachusetts Avenue \\ Cambridge, MA 02138 \\ December 2000
}

This study would not have been possible without the generosity of Irving Stone, who supplied detailed information documenting British foreign investment that was not published in his book. We are also grateful to Robert Allen, Chris Meissner and Luís Bertola who kindly provided some of their unpublished data. The authors thank John Baldiserotto, Ximena Clark, John Collins, David Foster, Heather McMullen, Ann Richards, and Danila Terpanjian for their excellent research assistance. We have benefited from discussions with John Coatsworth, Daniel Devroye, Scott Eddie, David Good, Yael Hadass, Matt Higgins, Macartan Humphreys, John Komlos, Philip Kuhn, Kevin O'Rourke, Matt Rosenberg, Howard Shatz, Max Schulze, Alan Taylor, and Andrew Warner. Remaining errors belong to us. Williamson acknowledges with pleasure financial support from the National Science Foundation SES-0001362, and both authors thank the Center for International Development for allocating office space to the project. The views expressed in this paper are those of the authors and not necessarily those of the National Bureau of Economic Research.

(C) 2000 by Michael A. Clemens and Jeffrey G. Williamson. All rights reserved. Short sections of text, not to exceed two paragraphs, may be quoted without explicit permission provided that full credit, including (C) notice, is given to the source. 
Where did British Foreign Capital Go? Fundamentals, Failures and the Lucas Paradox: 1870-1913

Michael A. Clemens and Jeffrey G. Williamson

NBER Working Paper No. 8028

December 2000

JEL No. F21, N20, O1

\section{$\underline{\text { ABSTRACT }}$}

A decade has passed since Robert Lucas asked why capital does not flow from rich to poor countries. Lucas used a contemporary example to illustrate his Paradox, the very modest flow of capital from the United States to India during the second great global capital market boom, after 1970. Had he paid more attention to the first great global capital market boom, after 1870, he might have been less surprised. Very little of British capital exports went to poor, labor-abundant countries. Indeed, about two-thirds of it went to the labor-scarce New World where only a tenth of the world's population lived, and only about a quarter of it went to labor-abundant Asia and Africa where almost two-thirds of the world's population lived. Why? Was it caused by some international market failure, or was it due to some shortfall in underlying economic, demographic or geographic fundamentals that made capital's productivity low in poor countries? This paper constructs a panel data set for 34 countries who as a group got 92 percent of British capital, and uses it to conclude that international capital market failure (including whether the country was on or off the Gold Standard) was not involved. It then ranks the three big fundamentals that mattered—schooling, natural resources and demography.

Michael A. Clemens

Department of Economics

Harvard University

Cambridge, MA 02138

and Center for International Development

mclemens@fas.harvard.edu
Jeffrey G. Williamson

Department of Economics

Harvard University

Cambridge MA 02138

and NBER

and Center for International Development

jwilliam@kuznets.harvard.edu 


\section{Introduction}

\section{Lucas and Two Views}

A decade has passed since Robert Lucas (1990) asked why capital does not flow from rich to poor countries, posing what is widely known as the Lucas Paradox. His point that a simple neoclassical growth model makes empirically untenable predictions regarding differentials in the marginal product of capital between countries had been made before (e.g., Barro 1989; King and Rebelo 1989), but Lucas' concise statement spawned the debate that continues today.

L ucas used a contemporary example to illustrate his paradox, the very modest flow of capital from the U nited States to India during the second great global capital market boom, after 1970. Had he paid more attention to the first great global capital market boom, after 1870, he might have been less surprised. Table 1 summarizes British investment experience abroad just prior to W orld War I, and very little of it went to poor, capital-scarce and laborabundant countries. Indeed, about two-thirds of it went to the labor-scarce $\mathrm{N}$ ew W orld where only a tenth of the world's population lived, and only about a quarter of it went to laborabundant A sia and A frica where almost two-thirds of the world's population lived. The simplest explanation of this apparent paradox is that British capital chased after European emigrants and that both were seeking cheap land and other natural resources ( $O^{\prime}$ Rourke and Williamson 1999, Chap. 12), although Table 1 shows that F rench and German capital did not chase after the emigrants anywhere near as much as did the British. While F rench and 
German capital preferred European to N ew World opportunities, the same small shares of went to A sia and A frica. ${ }^{1}$

The venerable capital-chased-after-labor explanation argues that there must have been an omitted third variable at work, and most economic observers of the late 19th century would say that the omitted variable was natural resources. In contrast, most economic observers of the late 20th century would say it was human capital. But surely the paradox deserves more serious attention than that offered by some mono-causal natural resource or human capital endowment explanation. In addition, we want to explore other explanations recently offered by economic theorists as well as some old chestnuts that have lain on the historical forest floor for some time. Furthermore, we want to sort out what role policy and institutions played in the process-like the gold standard-after we have controlled for the economic, demographic and political fundamentals. Finally, we hope to combine this study of late 19th century British investment abroad with a similar study of late 20th century U nited States investment abroad (Clemens ongoing) to learn how the main forces accounting for the paradox have changed with time.

The debate over the cause of the Lucas Paradox breaks down into two camps: those who believe that capital is in fact highly productive in poor countries but does not flow there due to failures in the global financial capital market or in the global capital goods market, and those who believe that capital would not be very productive in poor countries even with perfect capital markets and thus has no reason to flow there. Proponents of the neoclassical revival in growth economics tend to fall into the former camp, while endogenous growth

\footnotetext{
${ }^{1} U$ nfortunately, we have not been able to secure the same kind of panel data for France and Germany that is available for Britain in the four decades prior to W orld War I. Too bad, since we'd like to see whether F rench and German investors obeyed the same laws of motion that characterized British investors, even though the latter favored the $\mathrm{N}$ ew World.
} 
economists tend to fall in the latter. We shall refer to the first claim as the capital market failure view, and the second as the unproductive capital view.

These two camps have their counterparts in the economic (social, political and world) history literature, and it is that literature which we stress in the summary that follows. ${ }^{2}$

\section{What M ight Explain the Direction of British Capital Flows?}

\section{The Capital M arket $F$ ailure View}

The wide range of studies positing failure of a perfectly competitive international capital market invites the following organization. The demand for foreign savings can be choked off by tariffs and other distortionary policies that prevent capital goods price equalization, resulting in wide user cost differentials between countries even where financial costs are equalized. The supply of foreign savings can be deflected by a gamut of other capital market failures, like adverse selection, herding, unenforceable property rights, the absence of a stable monetary standard, and colonial intervention through the application of force. Each will be discussed in turn.

Tariffs, Transport Costs and Other Distortions. M atthew Higgins (1993; summarized in Taylor 1998) demonstrates that after correcting for higher prices of capital goods in many contemporary less development countries (LDCs), much of the incentive to invest in those countries evaporates. Empirical work by Charles J ones (1994) on the years following 1950, and William Collins and J effrey Williamson (2000) on the years before 1950, extend the investigation of J. Bradford D eL ong and Lawrence Summers (1991) to show

\footnotetext{
${ }^{2}$ A recent survey of empirical literature on the L ucas Paradox can be found in Clemens (2000).
} 
that distortions in equipment prices significantly depress domestic investment as well as growth. What distortion might prevent the capital market from sending enough financial capital to poor countries where the marginal product of capital is high? The idea that tariffs on manufactures early in industrial development could deter capital flows, by decreasing the "national dividend" from which that capital takes its return, is as old as List (1856, pp. 227, 314) and Pigou (1906, p.11). ${ }^{3}$ Transport costs might do the same. Citing the example of A rgentina after the 1930s, A lan Taylor (1998) shows how fiscal indiscipline, overvalued currencies and import substitution policies-and their accompanying price distortions-can stifle capital flows even when the undistorted marginal product of capital is high. Collins and Williamson, however, show that the late 19th century was very different than the 20th century explored by DeL ong, Taylor and Summers, since tariffs lowered the relative price of capital goods in the previous case where equipment was much less tradable (Collins and Williamson 2000, Table 4) while they raised them in the latter case where equipment was much more tradable.

Adverse Selection. A pplying asymmetrical information theories, several authors have argued that the international credit market is rationed by adverse selection. That is, wealthy investors will not accept the high returns to capital available in developing countries because the presence of that capital may attract high-risk borrowers, creating potential losses which exceed the gains due to otherwise outstanding investment opportunities.

H erding and the Foreign Bias. One of the older hypotheses used to explain Victorian and Edwardian Britain's economic slowdown and alleged failure was that the City of L ondon systematically discriminated against domestic borrowers, starved the home industry for funds

\footnotetext{
${ }^{3} \mathrm{O}^{\prime}$ R ourke (2000) provides evidence that protective tariffs raised TFP before WW 1 in ten economies more advanced in
} 
by an irrational foreign bias, thus contributing to an accumulation slowdown. A ccording to this thesis, market failure at home accounts for the huge capital export from Britain (O'Rourke and W illiamson 1999: p. 226). Evidence offered by M ichael Edelstein (1976, 1981, 1982) certainly did grave damage to the thesis, but it may still have power in accounting for the heavy preference for $\mathrm{New}$ W orld investment. A fter all, this foreign capital export boom seems to be characterized by the same attributes theorists assign to herding behavior in financial capital markets today (Banerjee 1992; Cont and Bouchaud 2000).

Unenforceable Property Rights. Even if an investor can easily prove noncompliance to an investment contract, this information is of little use if the enforcement mechanism is inadequate or, even worse, non-existent. Thus, foreign investment will not take place in potential-borrowing countries where contract enforcement and property rights are absent, and wide differences in the marginal product of capital can exist. Contracts may be unenforceable due to the absence of needed judiciary and executive public institutions, both at the national and international level. A arón Tornell and A ndrés V elasco (1992) proposed just such an explanation for low capital flows to poor countries. Sometimes these capital flows can even be negative, as in Cecil Rhodes' Africa, when rents from mines underwent capital flight to rich countries where returns were low but property rights were enforced by law rather than by gunpowder and steel. Riccardo Faini (1996) offers another example. He shows how labor mobility out of countries with low capital stocks-like 19th century Ireland and Italy-toward those with high capital stocks (and thus high wages) - like the $\mathrm{N} \mathrm{ew}$ World-can keep the marginal product of capital low even in countries with low capital: by 
depopulation. Since labor cannot be used as collateral for loans no matter how profitable, these countries cannot borrow against their labor force to build sufficient physical capital stocks to prevent the emigration.

Stable M onetary Systems. The global economy was dominated by the gold standard after the 1870s, when the German Reich and the post-Civil W ar U nited States joined much of the rest of Europe. M any observers argue that the gold standard promoted international capital mobility by eliminating exchange risk (as summarized in Eichengreen 1996). Others argue that the gold standard commitment provided an investor guarantee that the country in question would pursue conservative fiscal and monetary policies (Bordo and Kydland 1995; Bordo and Rockoff 1996), policies that would make potential investors more willing to risk their capital overseas. While the argument certainly seems plausible, it is, of course, possible that the gold standard policy choice and the foreign capital inflow were both determined by more fundamental influences. Barry Eichengreen (1992) has persuasively argued the case for these political and economic fundamentals, a position taken some time ago by Karl Polanyi (1944) and restated in modern economic language recently by M aurice Obstfeld and Taylor (1998).

Colonial Intervention. The late 19th century was a remarkably peaceful and stable era, and colonial intervention (plus gun-boat diplomacy) created a friendly environment for international lending, or so says a very large literature. After controlling for other things that mattered to investors, did British foreign capital follow the flag or follow the market?

\section{The Unproductive Capital View}


The alternative view of the L ucas Paradox is to explain it by appealing to absent and critical third factors. This unproductive capital view actually assumes perfect financial capital markets, although it stresses that there may be failures in other markets that might impact on this one. The supply of foreign capital may be cut back by positive correlations of business cycles between developed and developing countries, since wealthy-country investors seek both high average returns and insurance against financial disaster that a diversified portfolio offers. The demand for international investment can be choked off by limitations on internationally immobile third factors such as schooling, skills, natural resources, urban agglomerations, specialized intermediate inputs, and what has come to be called social capital (Putnam 1995).

Business Cycle and Long Swing Correlations. Several economists (Cox et al. 1985; Tobin 1992; Bohn and Tesar 1996) have sought to explain gross (rather than net) capital flows by the increased supply of foreign capital available to countries with business cycles uncorrelated or, even better, inversely correlated with that of the host country, allowing portfolio diversification for investors in the latter. This theoretical view will find a comfortable haven in history since the inverse pre-1913 correlation between British domestic investment and capital exports has long been appreciated by economic historians, often called long swings by the literature written in the 1950s and 1960s (Cairncross 1953; Thomas 1954; Williamson 1964; A bramovitz 1968; Easterlin 1968; Edelstein 1982). Perhaps this correlation in the aggregate also played a role in influencing the direction taken by British foreign capital.

Internationally Immobile Third F actors. Consider a neoclassical production function $Y=A K^{\alpha} L^{\beta} S^{\gamma}$, where $S$ is some third factor and there are constant returns $(\alpha+\beta+\gamma=1)$. 
Taking derivatives, the marginal product of capital $Y_{k}$ and the marginal product of labor $Y_{L}$ are

$$
\begin{aligned}
& Y_{K}=A \alpha K^{\alpha-1} L^{\beta} S^{\gamma} \\
& Y_{L}=A \beta L^{\beta-1} K^{\alpha} S^{\gamma}
\end{aligned}
$$

It is easy to see that low marginal products of capital and low marginal products of labor can coexist-provided the country is sufficiently poor in S.

The economic history literature would be quick to offer a candidate for this immobile third factor role- natural resources, and David Bloom and J effrey Sachs (1998) have argued the same case when looking for explanations of A frican performance more recently. It has a venerable tradition in economic history, ${ }^{4}$ and we will give that tradition plenty of scope to influence the empirical results later in this paper.

In his original note, however, Lucas took the view that the immobile third factor was human capital-skills and schooling. While there are reasons to suppose that human capital was much less central to the growth process in the 19th than in the 20th century, Gabriel Tortella (1994) has effectively argued the contrary to help account for I berian backwardness. K evin O'Rourke (1992) gets the same result by introducing the assumption of asymmetry between physical capital and labor in his study of 19th century Irish emigration. If Irish workers with the greatest human capital endow ments self-selected for emigration, effective labor per worker in Ireland might have decreased with respect to Britain, meaning that effective capital-labor ratios, and thus capital's marginal product, might have converged between Ireland and Britain, thus choking off the capital flow from Britain across the Irish Sea. Similarly, the work of Gregory Clark (1987) on cotton textile mills across the globe just

\footnotetext{
${ }^{4}$ The literature is large. See, for example, Cairncross 1953; DiT ella 1982; Green and U rquhart 1976; Kuznets 1958; O'Rourke and Williamson 1999: Chap. 12.
} 
before W orld W ar I shows enormous differences in profitability, and cheap labor did not help poor countries since it was very unproductive. However, Clark thinks it was local environmental and cultural forces that reduced worker productivity rather than skills and schooling per se.

Consider another immobile third factor that might influence international capital flows. The dependency ratio, defined as the percentage of the population not engaged in productive activities (whether remunerated or not), is typically viewed as an immobile characteristic of a country's labor force. It increases in response to baby booms, improved child survival rates and adult longevity, although the latter was a minor event in the 19th century. A ssuming that dependents affect a household's ability to save and that labor force participation affects productivity and therefore investment, dependency rates have the potential to impact capital flows. Demographic models like those of Higgins and Williamson (1997) and Bloom and Williamson (1998) show how changes in the demographic structure can matter. As the country develops, the demographic transition to a lower youth dependency burden and a more mature adult population increases the productivity of both the population and the labor force. Further development, of course, can reverse the effect as the elderly dependency burden rises.

In order for the demographic structure to affect capital flows in a perfect capital market, it must have differential effects on investment and savings. Its effect on investment is clear from the simple third factor equations above: lower youth dependency and higher adult participation rates means a higher marginal product of capital, which, in turn, implies more investment demand. And more investment demand implies more demand for foreign capital unless domestic savings increases. The response of domestic saving to a change in 
the dependency burden is, however, less clear as those who have followed the debate over the life cycle model know. While the negative impact of the youth dependency rate on saving is often ambiguous on modern evidence, ${ }^{5}$ it is unambiguous on late 19th century evidence (Taylor and Williamson 1994 and). In the absence of any direct information on investment demand, we expect the dependency rate to play a role in determining capital flows, young populations being more dependent on foreign capital.

There are other candidates for the immobile third factor role. In their recent efforts to reclaim the importance of geography on late 20th century economic performance, Bloom and Sachs (1998) stress distance from periphery to core, a factor which is likely to have been even more important in the 19th century when distance had a bigger impact on cost. Helmut Reisen (1994) has explicitly pointed to the potential role of geographic distance to neighboring markets and urban agglomerations on capital flows. The seminal industrial organization theories of Raymond V ernon (1966) and Stephen Hymer (1976) fall into this category as well; their vision of scale effects, managerial knowledge, distribution networks, product cycles and other firm-specific intangibles can all be modeled as immobile third factors affecting the marginal product of capital. Others have explored yet another immobile third factor-specialized, nontraded intermediate inputs.

It is very clear that we have enough theoretical assertions to motivate empirical analysis. What's missing in the literature on the Lucas Paradox, however, is the empirical analysis, and at this point economic history has much to offer.

\section{Where Did British Capital G o?}

\footnotetext{
${ }^{5}$ But see the late $20^{\text {th }}$ century results reported by Higgins and Williamson (1997).
} 
The L ucas Paradox badly needs an empirical test. To do so, modern social scientists have gone to Ghanaian factory floors in search of unproductive capital (e.g. Bigsten et al. 1998) and they have polled investment bankers in search of international capital market failure (e.g. Bhattacharya et al. 1997). While these methods of settling the question are inaccessible to historians, we do have volumes of indirect information on foreign capital productivity and market failure which was generated by the actions of British investors prior to 1914. We do not know for sure how they made their decisions, but we can make inferences if we are willing to assume that they wished to maximize returns.

To the degree that return-maximizing international investors were attracted to or deterred from countries with fundamental national characteristics which affected in equal measure the returns to national or international investors, we can reject the capital market failure view. ${ }^{6}$ To be precise, we say that the market for British capital exports exhibits the L ucas Paradox when a country's GDP per capita-without any other explanatory variables present-has a powerful positive affect on the share of total British capital exports received by that country. We say that we "explain" the Lucas Paradox when variables representing country fundamentals and market failure have a statistically significant effect on British capital inflows and GDP per capita loses its positive significance.

We turn now to the recorded behavior of British overseas investors between 1870 and 1913, the first great globalization boom. We choose British capital for two reasons. First, the British evidence is available, and it is not for other capital exporters. Second, Britain

\footnotetext{
${ }^{6}$ Remember that this view posits international capital market failure rather than domestic capital market failure; the latter implies unproductive capital for investors of all flags. N ote also that the converse of our test is not true. That is, while the determination of flows by fundamental national characteristics is sufficient to reject the capital market failure view, lack of such determination is merely a necessary condition to reject the unproductive capital view.
} 
was then the world's leading capital exporter, far exceeding the combined capital exports of its nearest competitors, France and Germany (F eis 1930, pp. xix-xxi, 71). London was, quite simply, "the chief abode of the great god M oney" (Turner 1900, p.33). The keystone of our analysis is the data on gross British capital exports collected by Leland J enks and M atthew Simon, as reported by Irving Stone (1999; 2000), broken down annually by destination and type.

As potential determinants of those flows, we have assembled, from the ground up, a large database documenting 34 of the 36 countries which received most of the British capital during this period. The two countries eliminated, Rhodesia and South A frica, present insurmountable data-collection challenges. In 1914, our 34 countries held approximately $86 \%$ of the world's population, produced $97 \%$ of the world's GDP, and received $92 \%$ of British capital exports. ${ }^{7}$

The database, which the Data A ppendix discusses in detail, contains a range of variables related to market failure and capital productivity. On the capital market failure side, it includes import duties as a fraction of total import value, colonial affiliation, monetary regime, exchange rate variance against the pound sterling, changes in the terms of trade, and an index combining shipping costs and distance from L ondon. On the capital productivity side, it includes the youth dependency ratio, net immigration rates, primary school enrollment rates, urbanization, and indices of natural resource abundance made popular by Jeffrey Sachs and Andrew Warner (1995). The database also includes real PPP-

\footnotetext{
${ }^{7}$ The countries are A rgentina, Australia, A ustria-H ungary, Brazil, Burma, Canada, Ceylon, Chile, China, Colombia, Cuba, D enmark, Egypt, France, Germany, Greece, India, Indonesia (Dutch East Indies), Italy, Japan, M exico, New Zealand, Norway, Peru, the Philippines, Portugal, Russia, Serbia, Spain, Sweden, Thailand (Siam), Turkey (Ottoman Empire without Egypt and European territories), the USA, and U ruguay. See Data A ppendix.
} 
adjusted unskilled urban wages relative to Great Britain for thirty countries, and prices of capital equipment for eight.

Each data point represents one country in each of six time periods, shown in Figure 1. The decision to aggregate our annual data into multi-year periods was based on a desire to defuse the effects of outlier years and the need for a right-hand side matrix of significant variance. Six periods were chosen to utilize local minima as divisions between successive waves of outflows. Economic historians since Hobson (1914, pp. 142-9) have divided prewar British capital exports into three periods, separated by two large troughs. The first corresponds to a depression in the aftermath of the Franco-Prussian war and a series of defaults in 1874, and the second to economic collapse in A rgentina, A ustralia, and elsewhere in 1890-91. We exploit minor local minima to achieve a slightly higher resolution, balancing the need to aggregate against our desire to reveal dynamic changes in flow determinants. ${ }^{8}$

Unlike most studies of British capital exports, ${ }^{9}$ ours focuses exclusively on what pulled British capital into some countries versus others, rather than what pushed it out of Great Britain. Our dependent variable is therefore the value of total British capital exported to a given country during a given period as a fraction of all British capital exported during that period. Push effects are thus entirely eliminated. Population scale effects are eliminated by the inclusion of log population share on the right-hand side. ${ }^{10}$

\section{The Determinants of Capital Destination}

\footnotetext{
${ }^{8} \mathrm{~A}$ nother concern influencing the division of flows into periods was the possible creation of a large number of lefthand-side zeros in a given period if the divisions were too fine, with the consequent risk of censored data and material non-linearities. Given our six-period division, an average of 2.2 countries out of 34 received no British capital in each period, with the largest number being 4 countries (in Period I) and the smallest number being 0 countries (in Period VI).

${ }^{9}$ E.g. Cain and Hopkins (1980) or Richardson (1972).

${ }^{10}$ Population Share is country population divided by the sum of the populations of all 34 countries in the first year of the
} 
Rejecting Capital Market F ailure. Our central result, presented in Table 2, is that the L ucas Paradox was alive and well during 1870-1913, and that it can be explained during 1894-1913 in a way that is sufficient to reject the capital market failure view.

Note first the significant, positive effect of GDP per capita (alone) on flows-the original puzzle expounded by Lucas. During the period of a relatively thin and volatile international market for British capital through the 1880 's, the positive effect of GDP per capita on flows survives the inclusion of proxies for market failure and of fundamental national characteristics. Following the early 1890's, however, the Paradox does not survive the inclusion of other variables: after accounting for the significant capital attraction of natural resource abundance and (after the turn of the century) education, population growth and immigration, the Paradox disappears. Since fundamental national characteristics can explain the Paradox during this period, there is little room left for the capital market failure view.

There is a notable exception to this story, namely the significant negative impact of transport costs on flows during period VI. This might come as no surprise, since it was between 1907 and 1912 that transoceanic shipping costs-which had been in general decline since 1870-spiked upwards and gained back half the ground they had lost in the previous 37 years (Isserlis 1938). How can we gauge the relative importance of this indicator of capital market failure during period VI against the several significant indicators of unproductive capital? First, no other capital market failure indicator mattered-not the Gold Standard, not the height of tariffs, and not colonialism. Second, we are skeptical that transport costs can fully explain the Paradox in period VI, given that unproductive capital fundamentals were 
able to explain it fully in period $\mathrm{V}$ without any significant help from transport costs. Third, only around one eighth of the explained variation in flows during period VI is due to transport costs-an indicator of market failure.

The results in Table 2 are robust to several changes of specification. Consider just two examples. If, instead of the fraction of the period the country was on the Gold Standard, we substitute the fraction of the period the country was on a gold, silver, or bimetallic standard, the variable remains insignificant in all periods. Substituting the real PPP-adjusted urban wage relative to that of Great Britain for GDP per capita does not significantly change the results either. ${ }^{11}$

I dentifying the $\mathrm{F}$ undamentals That $\mathrm{M}$ attered. Which of the underlying fundamentals measured here were doing most of the work in dictating where British capita went? One useful way of sorting out important from unimportant variables is to calculate "beta coefficients. ${ }^{12}$ When we make this calculation for the last period-the years 1907 to $1913-$ here is what those beta coefficients look like in absolute value: fraction of children enrolled in primary school, 0.92 ; primary product share in exports, 0.81 ; immigration, 0.51 ; transport costs, 0.36 ; and population growth rate, 0.30 . This suggests that fundamentals that mattered most were good endow ments of education, skills and schooling plus natural resources. Still, demographic forces mattered too, here captured by immigration and population growth. As we pointed out above, the only capital market failure variable that mattered was transportation cost, and it takes a distant fourth place.

\footnotetext{
${ }^{11}$ However, using real wages does decrease the significance of education in period VI (down to being significant merely at the $16 \%$ level). This is hardly a surprise, since higher real wages capture some of the effect of increased human capital.

${ }^{12}$ Defined as the estimate of the coefficient on the variable in question multiplied by the ratio of the standard deviation of the underlying explanatory variable to the standard deviation of the dependent variable. Although without formal statistical content, the beta coefficient can be interpreted as the number of standard deviations of the regressand explained by one standard deviation of the regressor, and is one indication of the relative "importance" of different
} 
Since the measurement of "natural resource endowment" can be (and has been) debated, and since the variable joins schooling for top billing, some sensitivity analysis is in order. Substituting land area for primary product share of exports gives positive and significant coefficients only in periods I and VI. Both of these variables were popularized as indicators of natural resource abundance by Sachs and W arner (1995). L and area can capture many effects potentially deterrent to capital flows that are unrelated to resource abundance, such as the deterrence of low population density to the creation and diffusion of new technologies. A third indicator they used, primary product-based exports as a share of GDP, only carries a positive and significant coefficient in period I. This variable, however, also has limitations as an indicator of natural resource abundance in a nineteenth century context. $M$ any countries in the sample exported almost entirely primary products, making this variable highly correlated with the size of the export sector relative to the economy. Since much of British capital was invested in export-related industries, there is reverse causation from British capital investment on the left-hand side to the share of exports in GDP, and therefore to the share of primary product-based exports in GDP. This endogeneity makes coefficients on the variable suspect.

The Deepening of Capital Markets Through Time. What made flows respond to fundamentals after 1894 more than they had previously? Figure 1 suggests that the international capital market was simply deeper than it had been before. ${ }^{13}$ Transoceanic trade awoke from post-Boer War depression, the Russo-J apanese war stimulated borrowing, the Canadian and Argentine railways expanded, and British capital spread to a wider area than ever before-including major movements to Brazil, M exico, Chile, Egypt, South A frica, 
India, Russia, and the Far East (Hobson 1914, pp. 157-8). The speculative bubbles

surrounding A merican range-cattle in the 1880's and A ustralian construction in the 1890's had burst and gone (Court 1965, pp. 216-225), and the A rgentine-located Baring crisis was

over. Herbert Feis (1930, pp. 12-13) puts it thus:

Changing political relations took British capital into countries from which it had previously abstained--) apan [Alliance of 1902], Russia [A nglo-Russian agreement, 1907], and Turkey. But more important than these causes in producing a great growth in foreign investment was the fact that during the 1900-1914 period those distant lands to which the capital had been going in earlier periods, seemed to have overcome the risks and crashes of their first growth. Now in the greater stability and greater order of their development, they needed still more capital than before and offered surer return. $\mathrm{Or}$-the idea presents itself in alternative form-it was as though many regions of the world in which British capital had invested itself had come to fit themselves better for the investment, learning from pioneer failures. In their use of capital they were tending to resemble more and more the land from which the capital came. ... In spite of the deferring influence of financial stringency, losses, war, and the like, there comes to the observer of this process of British capital investment a sense that the great increase in investment that occurred after 1900 had been prepared by the earlier investment. Conditions were created which made the borrowing regions more safely penetrable, capable of using more capital well ...

We suspect that regularities dictating who got British capital prior to 1894 are hidden by a thin global market for that capital. The deepening of that market after 1893 allows us to better isolate the determinants of those flows. It is here that the evidence rejecting capital market failure explanations of the Lucas Paradox is strongest.

\section{Capital F lows to Governments and to the Private Sector}

Disaggregating capital flows by recipient sector allows us to learn even more about how they were determined. Table 3 shows that during most of the prewar years, British

\footnotetext{
${ }^{13} \mathrm{~A}$ bout $60 \%$ of British capital exports that occurred during 1870-1914 flowed after 1894 .
} 
capital exports were primarily invested in the private sector of the destination country. What drove these private and public flows, and how did they interact?

Tables 4 and 5 repeat the estimation presented in Table 2, but break it down by the private and public recipient distinction. Investment in the private sector drives the results in Table 2; there is in fact little meaningful difference between the determinants of total flows and those of flows to the private sector. While Table 4 (private-sector recipients) closely resembles Table 2 in all aspects, Table 5 (public-sector recipients) does not. A bundant anecdotal evidence suggests that warfare was the main determinant of demand for sovereign borrowing, which in itself would make capital flows to governments unrelated to recipient country characteristics even without international market failure. There were massive loans to the French and German governments during the Franco-Prussian War in the 1870 's, to the South A frican government at the time of the Boer War in the 1890 's, and to the J apanese government to finance its war with Russia just after 1900. For each of these countries, total wartime sovereign borrowing dramatically exceeded the cumulative total of all peacetime borrowing during the five decades that preceded the First World War. Contemporary observers (e.g. van Oss 1898, p. 228) likewise identified warfare as the primary determinant of sovereign borrowing from Britain.

We must be cautious, however, in drawing a hard and clear line between flows to governments and flows to the private sector, as Simon, Jenks and Stone defined them. For one thing, government involvement in many of these "private sector" loans tended to be heavy-especially in the case of railroads, the largest category of private sector borrowing. Whether through land grants, subsidies, or loan guarantees, governments were indirect partners to many private sector investments (Nurkse 1954, p. 749). Furthermore, when 
analyzing these flows from the perspective of the 21st century, we must remember that most of these private-sector flows went to investments in what Simon (1968, p. 23) calls "social overhead capital." These included projects with significant positive external effects, projects like railroads and public utilities, today often undertaken by government borrowers.

Based on the behavior of British flows to the private sector, we have rejected the capital markets failure view. But what can we say about government-bound British flows? Does the capital market failure view apply here? Lack of evidence supporting the unproductive capital view is a necessary condition for acceptance of the capital markets failure view, but it is not sufficient. A fter all, this necessary condition could easily be brought about by demand effects such as wartime borrowing unrelated to either country fundamentals or market failure, and there is ample anecdotal evidence that this was indeed the case. Still, historians such as Feis (1930, pp. 98-117) have documented highly unreliable contract enforcement efforts by the British government on behalf of British investors in foreign governments-suggestive of widespread failure in the sovereign debt market. In spite of the Palmerston Circular of 1849 , proclaiming a "national duty" to intervene with foreign governments to protect British investors (F eis p. 103), many shirts were lost in the sovereign debt crisis of 1876 (Court 1965, p. 216). In other episodes such as the Baring crisis following massive default on A rgentine sovereign loans, the British government and central bank did step in (Ferns 1960, p. 459). It appears that such interventions were often guided more by British political or territorial aspirations than by a sense of duty to its investors. Feis describes intervention on behalf of British investors in the Egyptian case as secondary to the primary goal to secure influence over the Suez Canal (p. 108). In light of these 
qualitative accounts, we cannot reject capital market failure explanations for governmentbound flows, but we can and do reject capital market failure for private-sector-bound flows.

\section{Did Investment in Governments Crowd In Private Investment?}

The analysis presented in Table 6 suggests that previous investment in governments "crowded in" subsequent private sector investment. For this table, capital flow data were divided into ten periods of five years each, spanning 1865-1914, and the figure for flows within a given period represents total flows of that type during all five years. Thus, "lagged" refers to the five-year period preceding the one in question. Because two lags were necessary for the panel fixed-effects model, the number of observations is (34 countries x 10 periods) (34 countries $\times 2$ lags $)=272$. Similarly, the A nderson- $\mathrm{H}$ siao estimator, which uses 3 lags, lowers the number of observations to 238 .

The panel fixed-effect estimates reveal a positive effect of lagged public sector investment on current private sector investment (significant at 9\%), while the effect of lagged private sector investment on current public sector investment is much smaller and insignificant. It is well-known, however, that inclusion of a lagged dependent variable in a fixed-effects panel regression can produce severely biased coefficients, especially for small panels like this one (Nickell 1981). Anderson and Hsiao (1981) offer a solution by instrumenting for the once-differenced dependent variable with the twice-differenced dependent variable. ${ }^{14}$ The results of this A nderson-H siao estimation are also reported in Table 6. The crowding-in effect of public sector investment on private sector is confirmed, and again no such causation is seen from private sector investment to public sector

\footnotetext{
${ }^{14}$ Judson and Owen (1996) use a M onte Carlo approach to demonstrate that the A nderson-H siao estimator essentially
} 
investment. It is no surprise that the coefficient estimate on lagged public investment as a determinant of current private investment increases in magnitude with the A nderson- $\mathrm{H}$ siao estimator, since both $\mathrm{Nickell}$ and J udson and $\mathrm{O}$ wen make it clear that the direction of the relevant bias would be negative in this case. Note the negative coefficient on past private investment as a determinant of current private investment, likely reflecting the fact that in each period private investment was expanding into countries that had never received it before. The lack of such a coefficient on public flows reflects the aforementioned patterns of public investment, which tended to grow large in wartime and fall thereafter, rather than progressively expanding.

\section{Equipment Prices and Expensive Capital Goods}

Equipment price series for this period are available in Collins and Williamson (2000, Table 2), but they are only available for eight countries, ${ }^{15}$ all of which fall at the upper end of the per capita income spectrum. The consequent degrees-of-freedom and sample-selection biases prevent inclusion of these prices in the Table 2 specifications. Thus, we cannot directly observe whether expensive capital goods in the recipient country choked off financial capital inflows from Britain, but we can make some qualified inferences based on the behavior of equipment prices with respect to the fundamental and failure variables whose effects on flows we have previously identified.

Collins and Williamson have al ready analyzed the determinants of their equipment price data (ibid., Table 4); Table 7 expands slightly on their results by including variables on

eliminates this bias, though it is not as efficient as other methods for small panels. 
schooling, transportation costs, and urbanization. The regressions of Table 7 take as their dependent variable the "relative equipment price ratio" - that is, equipment prices as a fraction of consumer goods prices in each country, divided by the same fraction for Great Britain. ${ }^{16}$ Just as Collins and Williamson predict, skill endowments decrease the relative equipment price ratio over time, while the effects of tariffs are ambiguous. Table 7 shows that nearly all of the variation in the relative equipment price ratio can be explained by transport costs and schooling-significant determinants of capital flows-but not by tariff barriers, which had little effect on capital flows. N ote the declining effect of shipping costs on equipment prices, as ocean travel got cheaper.

One interpretation of these results is that better-educated countries absorbed new technologies faster and could make their own equipment rather than import it, and those that imported it paid more for it when transportation costs were higher. A gain, the results are merely suggestive, and we can make no conclusion about the effects of equipment prices on flows without observing those effects. But it is indeed suggestive that high equipment prices are almost perfectly predicted by variables proven to predict low capital flows.

\section{Discussion and Historiography}

The question of whether pre-WWI British capital exports were driven by capital productivity or by market failure has been around at least since Hobson (1914), who was writing at the capital export peak. Hobson raised the question and then offered as an

\footnotetext{
${ }^{15}$ Canada, D enmark, Germany, Italy, Japan, Norway, Sweden, and the U nited States.

${ }^{16}\left(P_{e, j} / P_{c, j}\right) /\left(P_{e, G B} / P_{c, G B}\right)$, where $P_{e, j}$ denotes the absolute price level of equipment in country $j ; P_{c, j}$ denotes absolute price level of consumer goods in country j; and G B stands for Great Britain.
} 
explanation the declining importance of market failure and thus, presumably, the rising importance of capital productivity fundamentals:

The causes of foreign investment are primarily economic, and centre in the return which capitalists expect to derive from various kinds of investment, and in the risks and uncertainties which investors are willing to assume. Other things being equal, the investor will naturally prefer the investment that yields him the largest income. But it is often difficult to judge the quality of a possible investment in a distant land, especially when that land is inhabited by a different race of men, possessing different institutions, and speaking a strange tongue. Barriers to intercourse impede the flow of capital to those parts of the world where it would yield the highest return. ...This tendency, however, is now much weaker than it has been in the past ... (p. xii)

Were Hobson alive today, he probably would want to leave the above paragraph unchanged. ${ }^{17}$ A fter all, the evidence we have presented suggests that the largest capital exporter in history was indeed sending its money where it could earn the highest return, and that was where the fundamentals served to raise capital's productivity. Our answer to Hobson's question is not new. A s E delstein $(1982$, p. 7) points out, the idea that third factors like land could allow for increasing returns to British capital exports in newly-settled regions goes back at least to A dam Smith (1776, pp. 89-93). Feis (1930, pp. 25, 31) also favored third-factor fundamentals by asserting that the "British investor was sending his capital where there was the growth of youth, and where the land was yielding riches to the initial application of human labor and technical skill," undeterred by "[s]trong risks, bad climates" and "isolation." A fter clearly identifying the L ucas Paradox by stating that "income per head in the principal debtor countries of the nineteenth century-the newly settled regions-can never have been far below European levels," Ragnar Nurkse (1954, p. 757) also concludes that capital was attracted "not to the neediest countries with their 'teeming millions,'" but rather

\footnotetext{
${ }^{17}$ However, he might wish to revise his sanguine 1914 prediction that "the opening up of the world will proceed with unexampled celerity" (p. 161).
} 
chased the "great migration" to the "spacious, fertile, and virtually empty plains" of certain countries (pp. 745, 750).

\section{Things That Didn't M atter}

The contribution of this paper has been to provide statistical confirmation of the above views (which precede those of Lucas) and to weigh them directly and favorably against competitors. We now consider several popular competing explanations of British capital flows for which there appear to be no empirical support.

Terms of Trade. We can find no evidence supporting the view that capital flows were driven by recent shocks to the terms of trade. Brinley Thomas (1968, pp. 49-50) felt that "movements in the terms of trade are to be looked upon more as consequences than as causal forces" of capital flows. "Cairncross [1953]," he writes, "has to go out of his way to find reasons why heavy British capital exports in the eighties should have coincided with a deterioration in the terms of trade of the borrowing countries, for the link seemed to work so well in the nineties and the 1900s." In defense of his critique, Thomas expounds a plausible model of causation from capital flows to terms of trade. Our results support his critique (but not necessarily his model).

Colonial Status. M any historians have view ed B ritish capital exports as part and parcel of British colonial expansion. This view appears reasonable in light of such developments as the 1900 revision of the Colonial Stocks Act, which promoted Empire investment by allowing registered securities in British colonies and dominions to be purchased by trust bodies and large institutional investors previously banned from foreign investment (F eis 1930, pp. 92-95). Y et, many have criticized this view by simply citing 
counter-examples like non-E mpire capital flows to A rgentina and the U nited States, that is, by implementing what amounts to a univariate regression. Simon (1968, p. 24), for example, uses such analysis to conclude that the "availability of abundant private ventures and the expanding needs of various public authorities, especially in the independent countries of the New World and to a lesser degree in Europe and A sia, more than counterbalanced the real or 'alleged' advantages associated with the protection of the British flag." Similarly, Platt (1986, p. 95) concludes that " $[b]$ efore the war, the benefits of investing outside the Empire were sufficient to overcome whatever slight advantage might exist for the British Dominions and colonies ..." What we add here is multivariate, quantitative support their univariate, qualitative analysis. Our results leave no doubt whatsoever that markets mattered far more than flag for private-sector British investment heading abroad.

The Gold Standard. Eichengreen (1996, p. 18) has stated unequivocally that in the 1870s, "[i]ndustrialization rendered the one country al ready on gold, Great Britain, the world's leading economic power and the main source of foreign finance. This encouraged other countries seeking to trade with and import capital from Britain to follow its example."18 How, then, do we interpret our inability to detect any significant influence of the Gold Standard on British capital flows? Was going on gold a misguided fad? Probably not, and here are five alternative explanations for our otherwise revisionist finding:

1) The effects of economic, demographic and geographic fundamentals simply outweighed the effects of the Gold Standard on capital flows. M ichael Bordo and A nna Schwartz (1996, p. 41) find anecdotal evidence that "adherence to the rule by A rgentina may have had some marginal influence on capital calls on new issues

\footnotetext{
${ }^{18}$ For an anecdote on how capital flows to Brazil stagnated after departure from the Gold Standard, see Eichengreen
} 
of securities in L ondon before $1890 \ldots$, but that the key determinant was the opening up of the country's vast resources to economic development once unification and a modicum of political stability were achieved." We confirm their finding on a far larger scale.

2) Flows may have reacted to the arrival of information about adherence to the Gold Standard rather than to actual changes in the monetary regime. A nalyzing both A rgentina and the United States, Bordo and Schwartz conclude that "events suggesting the restoration of convertibility during suspension and threats to convertibility during adherence seem to be associated with increases and declines in capital calls on new issues of securities in London" (1996, p. 44).

3) There may be measurement error in our indicator variable for adherence to the Gold Standard, given that varying degrees of de facto adherence often accompanied de jure adherence. Historians have debated, for example, the true monetary regimes of Italy and A ustria during this period (de Cecco 1996, p. 108).

4) Several historians document reverse causation from capital flows to Gold Standard adherence. If these effects were sufficiently large, the resulting endogeneity would throw into question our coefficients. M arcello de Cecco (1996, p. 105) records sly international arbitrageurs betting against the currencies of countries from which large sovereign debt payments were about to come due-to a degree that threatened their ability to maintain a fixed exchange rate. In a different mechanism of reverse causation, Jaime Reis (2000, p. 88) describes how transmission of negative macroeconomic shocks from the lending core to the 
borrowing periphery via the inflexible Standard might have motivated certain episodes of temporary abandonment of the rule. Furthermore, some authors (e.g. A ceña, Reis and Rodríguez 2000) define the 'Gold Standard' as the presence of fixed exchange rates, convertibility, and perfect capital mobility. That is, our Gold Standard variable on the right-hand side and our capital flow variable on the left-hand side could be simultaneously determined by unobserved capital mobility conditions (such as direct legislated capital controls).

5) Eichengreen and M arc Flandreau (1996) suggest that determinants of the adoption of the Gold Standard included the level of economic development, the size of the economy, imperial ties, and historical contingencies. Since we control for many of these factors, such causation would raise the possibility of colinearity between some of our included regressors and the Gold Standard variable-inflating standard errors on the latter.

\section{Conclusion}

We conclude that the evidence on British capital exports from the mid 1890s until the First World W ar rejects any international market failure explanation of the L ucas Paradox. British capital heading abroad, especially that invested in private enterprise, went where it was most profitable-chasing natural resources, educated populations, migrants, and young populations. Flows to private sector investment opportunities abroad were encouraged by previous investments in government-financed projects. 
We also should emphasize what our results do not imply. Our results do not suggest that international capital market failure was absent in the years leading up to the First W orld War. Rather, they suggest that the observed Lucas Paradox was not explained by international capital market failure. It is doubtlessly possible to imagine capital flows that, al though unobservable because market failure stopped them cold, would have gone primarily to capital-poor countries. One candidate for such flows is investment in manufacturing, which accounted for less than four percent of British capital exports (Simon 1968, p. 23). Edelstein (1982, pp. 41-2) points directly to market failure as the cause of this tiny figure, citing insuperable informational advantages of local manufacturers in local input and output markets. He also mentions the increasing importance of tariff barriers in keeping British manufacturing investment at home as the war approaches. Feis (1930, p.31) agrees, calling foreign industrial investment during this period particularly " risky, difficult to manage well from a distance." We can make no statement about whether or not such flows, had they occurred, would also have chased resources, education, migrants and youth. Given the variety of investment types represented by the flows we do observe, however, any assertion that other investment types were determined in a totally different fashion would require very strong evidence.

We have shown that market failure did not determine how large a slice of the Britishcapital-export pie was received by a given capital-importing country between 1894 and 1913 . Whether the relative size of that slice would have changed had the entire pie been augmented by a total absence of any international capital market failure during those years is an entirely different question that may never be answered. We have also shown that the major fundamentals that determined where capital went were, in order of importance, schooling, 
natural resource endowment, and immigration (plus other demographic features). Whether the fundamentals driving capital exports in the late 19th century were the same as those driving capital exports in the late 20th century is another question which can be answered, but must await future research.

One thing is certain: the Lucas Paradox was alive and well a century ago. 


\section{References}

A bramovitz, M ., 1968, "The Passing of the Kuznets Cycle," Economica 35: 349-67.

A nderson, T. W. and C. H siao, 1981, "Estimation of Dynamic M odels with Error Components," J ournal of the American Statistical Association, 76 (September): 598-606.

Banerjee, A. V., 1992, "A Simple M odel of Herd Behavior," Quarterly J ournal of Economics, 107 (3): 797-818.

Barro, R. J., 1989, “Economic Growth in a Cross-Section of Countries," NBER Working Paper 3120, National Bureau of Economic Research, Cambridge, M ass.

Bhattacharya, A., P. J. M ontiel, and S. Sharma, 1997, “H ow Can Sub-Saharan A frica A ttract M ore Private Capital Inflows?" Finance and D evelopment 34 (J une): 3-6.

Bigsten, A . et al., 1998, "Rates of Return on Physical and Human Capital in A frica's M anufacturing Sector," W orking Paper N 0. 98-12, Centre for the Study of A frican Economies, Institute of Economics and Statistics, U niversity of Oxford, Oxford, UK.

Bloom, D. and J. G. W illiamson, 1998, "D emographic Transitions and Economic M iracles in Emerging Asia," World Bank Economic Review 12 (3): 419-55.

Bloom, D. and J. Sachs, 1998, "Geography, Demography, and Economic Growth in A frica," Brookings Papers on Economic Activity, 2 (W ashington, D.C.: Brookings Institution): 207-95.

Bohn, H. and L. L. Tesar, 1996, "US Equity Investment in Foreign M arkets: Portfolio Rebalancing or Return Chasing?" American Economic Review, AEA Papers and Proceedings, 86 (M ay): 77-81.

Bordo, M. D. and H. Rockoff, 1996, "The Gold Standard as a 'Good Housekeeping Seal of A pproval'," J ournal of Economic History 56 (2): 389-428.

Bordo, M. D. and F. E. Kydland, 1995, "The Gold Standard as a Rule: A n Essay in Exploration," Explorations in Economic History 32 (October): 423-64. 
Bordo, M. D. and A. J. Schwartz, 1996, "The Operation of the Specie Standard: Evidence for Core and Peripheral Countries 1880-1990," in J. Braga de M acedo, B. Eichengreen and J. Reis, eds., Currency Convertibility: The Gold Standard and Beyond (N ew Y ork: Routledge).

Cain, P. J . and A. G. Hopkins, 1980, "The Political Economy of British Expansion Overseas, 17501914," Economic History Review, Second Series, 4 (N ovember): 463-90.

Cairncross, A., 1953, Home and Foreign Investment (Cambridge: Cambridge U niversity Press).

Clark, G., 1987, "W hy Isn't the Whole W orld Developed? Lessons from the Cotton M ills," J ournal of Economic History 47 (1): 141-73.

Clemens, M. A., 2000, "The Lucas Paradox Ten Y ears L ater: Where A re We and W here Do We N eed To Go?" mimeo., Department of Economics, Harvard U niversity (July).

Clemens, M. A., ongoing, "Where Has U S Foreign Capital Gone? The L ucas Paradox in the L ate $20^{\text {th }}$ Century."

Collins, W. J. and J. G. Williamson, 2000, "Capital Goods Prices and Investment: 1870-1950," J ournal of Economic History (forthcoming).

Cont, R., and J-P. Bouchaud, 2000, "Herd Behavior and A ggregate Fluctuations in Financial M arkets," Macroeconomic Dynamics 4 (June):170-96.

Court, W. H. B., 1965, British Economic History 1870-1914: Commentary and Documents (Cambridge: Cambridge University Press).

Cox, J. C., J. E. Ingersoll Jr., and S. A. Ross, 1985, "A n Intertemporal General Equilibrium M odel of Asset Prices," Econometrica 53 (M arch): 363-84.

de Cecco, M., 1996, "Short-Term Capital Movements under the Gold Standard," in J. Braga de M acedo, B. Eichengreen and J. Reis, eds., Currency Convertibility: The Gold Standard and Beyond (N ew Y ork: Routledge).

DeL ong, J. B. and L. Summers, 1991, "Equipment Investment and Economic Growth," Quarterly J ournal of Economics 106: 445-502. 
DiTella, G., 1982, "The E conomics of the Frontier," in C. P. Kindleberger and G. DiTella (eds.), Economics in the Long View, V ol. 1 (New Y ork: New Y ork University Press).

Easterlin, R. A., 1968, Population, Labor Force and Long Swings in Economic Growth (N ew Y ork: National Bureau of Economic Research).

Edelstein, M ., 1976, "Realized Rates of Return on UK Home and Overseas Portfolio Investment in the A ge of High Imperialism," Explorations in Economic History 13: 283-329.

Edelstein, M ., 1981, "Foreign Investment and Empire 1860-1914," in The Economic History of Britain Since 1700, V ol. 2, eds. R. Floud and D. N. M cCloskey (Cambridge: Cambridge U niversity Press).

Edelstein, M ., 1982, O verseas Investment in the Age of High Imperialism (N ew Y ork: Columbia University Press).

Eichengreen, B., 1992, Golden Fetters: The Gold Standard and the Great Depression 1919-1939 (Oxford: Oxford U niversity Press).

Eichengreen, B., 1996, Globalizing Capital: A History of the International M onetary System (Princeton, New Jersey: Princeton University Press).

Eichengreen, B. and M. Flandreau, 1996, "The Geography of the Gold Standard," in J. Braga de M acedo, B. Eichengreen and J. Reis, eds., Currency Convertibility: The Gold Standard and Beyond (New Y ork: Routledge).

Faini, R., 1996, "Increasing Returns, M igrations, and Convergence," J ournal of Development Economics 49: 121-36.

Feis, H., 1930, Europe, The World's Banker 1870-1914 (N ew Haven, Conn. : Y ale U niversity Press).

Ferns, H. S., 1960, Britain and Argentina in the Nineteenth Century (Oxford: Clarendon Press).

Green, A., and M. C. U rquhart, 1976, "Factor and Commodity Flows in the International Economy of 1870-1914: A M ulti-Country View," J ournal of Economic History 36: 217-52.

Higgins, M. D., 1993, “Why Capital Doesn't Flow from Rich to Poor Countries," mimeo., Department of E conomics, Harvard U niversity. 
Higgins, M. D., and J. G. Williamson, 1997, "A ge Structure Dynamics in A sia and Dependence on Foreign Capital, " Population and D evelopment Review 23 (2): 261-93.

Hobson, C. K., 1914, The Export of Capital (London: Constable).

Hymer, S. H., 1976, The International O perations of National Firms: A Study of Direct Foreign Investment (Cambridge, M ass.: M IT Press).

Isserlis, L., 1938, "Tramp Shipping Cargoes, and Freights," J ournal of the Royal Statistical Society 101 (1): 53-146.

Jones, C. I., 1994, "E conomic Growth and the Relative Price of Capital," J ournal of M onetary Economics 34: 359-82.

Judson, R. A. and A. L. Owen, 1996, "Estimating Dynamic Panel Data M odels: A Practical Guide for M acroeconomists," Federal Reserve Board of Governors, Washington, D.C., mimeo.

King, R. G. and S. T. Rebelo, 1989, "Transitional Dynamics and Economic Growth in the Neoclassical M odel," N BER W orking Paper 3185, National Bureau of Economic Research, Cambridge, M ass.

Kuznets, S., 1958, "Long Swings in the Growth of Population and in Related Economic Variables," Proceedings of the American Philosophical Society 102 (1): 25-52.

List, F., 1856, The National System of Political Economy (Fairfield, N ew J ersey: A ugustus M. Kelley Publishers, reprinted 1991).

Lucas, R., 1990, “Why Doesn't Capital Flow from Rich to Poor Countries?" American Economic Review 80 (M ay): 92-6.

Nickell, S., 1981, "Biases in Dynamic M odels with Fixed Effects," E conometrica 49 (November): 141726.

Nurkse, R., 1954, "International Investment To-D ay in the L ight of N ineteenth-Century Experience," Economic J ournal 64 (December): 744-58.

Obstfeld, M., and A. M. Taylor, 1998, "The Great Depression as a W atershed: International Capital Mobility in the Long Run," in M. D. Bordo, C. D. Goldin and E. N. White (eds.), The Defining 
M oment: The Great Depression and the American Economy in the Twentieth Century (Chicago: University of Chicago Press): 353-402.

O'Rourke, K. H., 1992, "Why Ireland Emigrated: A Positive Theory of Factor Flows," Oxford Economic Papers 44: 322-40.

O'Rourke, K. H., 2000, "Tariffs and Growth in the Late 19th Century," Economic J ournal 110 (A pril): 456-83.

O'Rourke, K. H., and J. G. Williamson, 1999, Globalization and History (Cambridge, M ass.: M IT Press).

Pigou, A. C., 1906, Protective and Preferential Import Duties (London: Frank Cass, reprinted 1968).

Platt, D. C. M., 1986, Britain's Overseas Investment on the Eve of the First World War: The U se and Abuse of Numbers (L ondon: M acM illan).

Polyani, K., 1944, The Great Transformation: The Political and Economic Origins of O ur Time (New Y ork: Rinehart).

Putnam, R., 1995, “Bowling A lone: A merica's Declining Social Capital," J ournal of Democracy 6 (January): 65-78.

Reis, J., 2000, "The Gold Standard in Portugal," in P. M artin A ceña and J. Reis, eds., M onetary Standards in the Periphery: Paper, Silver and Gold, 1854-1933 (N ew Y ork: St. M artin's Press).

Reisen, H., 1994, "Public Finance in Developing Countries and the A ttraction of Foreign Capital," in Debt, Deficits and Exchange Rates: Essays on Financial Interdependence and Development (Paris: Organization for E conomic Cooperation and D evelopment).

Richardson, H. W., 1972, "British Emigration and Overseas Investment," Economic History Review, Second Series, 25 (F ebruary): 99-113.

Sachs, J. D. and A. M. Warner, 1995, "N atural Resource A bundance and E conomic Growth," NBER Working Paper 5398, National Bureau of E conomic Research, Cambridge, M ass.

Simon, M., 1968, "The Pattern of New British Portfolio Foreign Investment, 1865-1914," in A. R. Hall, ed., The Export of Capital from Britain 1870-1914 (L ondon: M ethuen). 
Smith, A., 1776, An Inquiry into the Nature and Causes of the Wealth of Nations (N ew $Y$ ork: The M odern L ibrary, reprinted 1937).

Stone, I., 1999, The Global Export of Capital from Great Britain, 1865-1914 (N ew Y ork: St. M artin's Press).

Stone, I., 2000, personal communication.

Taylor, A. M., 1998, "On the Costs of Inward-L ooking Development: Historical Perspectives on Price Distortions, Growth, and Divergence in L atin A merica from the 1930s to the 1980s," J ournal of Economic History 58 (1): 1-28.

Taylor, A. M., and J. G. Williamson, 1994, "Capital Flows to the New World as an Intergenerational Transfer," J ournal of Political Economy 102 (A pril): 348-71.

Thomas, B., 1954, Migration and Economic Growth (Cambridge: Cambridge U niversity Press).

Tobin, J., 1996, "On the Internationalization of Portfolios," in Essays in E conomics: National and International (Cambridge, M ass.: M IT Press).

Tornell, A. and A. V elasco, 1992, "The Tragedy of the Commons and Economic Growth: Why Does Capital Flow from Poor to Rich Countries?" J ournal of Political Economy 100 (6): 1208-31.

Tortella, G., 1994, "Patterns of E conomic Retardation and Recovery in South-W estern Europe in the Nineteenth and Twentieth Centuries," Economic H istory Review 47 (1): 1-21.

Turner, C. C., 1900, "Living London" in R. C. M ichie, ed., The Development of London as a Financial Centre (New Y ork: I. B. Tauris Publishers).

Van Oss, S. F. ed, 1898, Introduction to Fenn on the Funds, 16th ed., L ondon., p. ix, reprinted in W. H. B. Court, 1965, British Economic History 1870-1914: Commentary and Documents (Cambridge: Cambridge University Press).

Vernon, R., 1966, "International Investment and International Trade in the Product Cycle," Quarterly Journal of Economics 80 (M ay): 190-207.

Williamson, J. G., 1964, American Growth and the Balance of Payments, 1820-1913 (Chapel Hill, North Carolina: University of N orth Carolina Press). 
Table 1: Distribution of European Foreign Investment 1913-1914 (in percent)

$\begin{array}{lrrr}\text { Destination } & \text { Britain } & \text { France } & \text { G ermany } \\ & & & \\ & & & \\ \text { E astern Europe } & 3.6 & 35.5 & 27.7 \\ \text { W estern Europe } & 1.7 & 14.9 & 12.7 \\ \text { Europe (not specified) } & 0.5 & 3.3 & 5.1 \\ \text { Total Europe } & 5.8 & 53.8 & 45.5 \\ \text { Latin A merica } & 20.1 & 13.3 & 16.2 \\ \text { North A merica and A ustral asia } & 44.8 & 4.4 & 15.7 \\ \text { Other N ew W orld (not specified) } & 2.8 & 0.0 & 2.1 \\ \text { Total New World } & 67.7 & 17.7 & 34.0 \\ \text { A sia and Africa } & 26.5 & 28.4 & 20.5 \\ \text { Total } & 100.0 & \mathbf{1 0 0 . 0} & \mathbf{1 0 0 . 0} \\ \text {----------------------------------------------------------------------- }\end{array}$

Sources and Notes: O'Rourke and Williamson (1999, p. 229), taken from Feis (1930). Columns may not add up due to rounding. Turkey is allocated to A sia. 
Figure 1: Division of Pre-WW 1 British C apital Exports into Six Time Periods

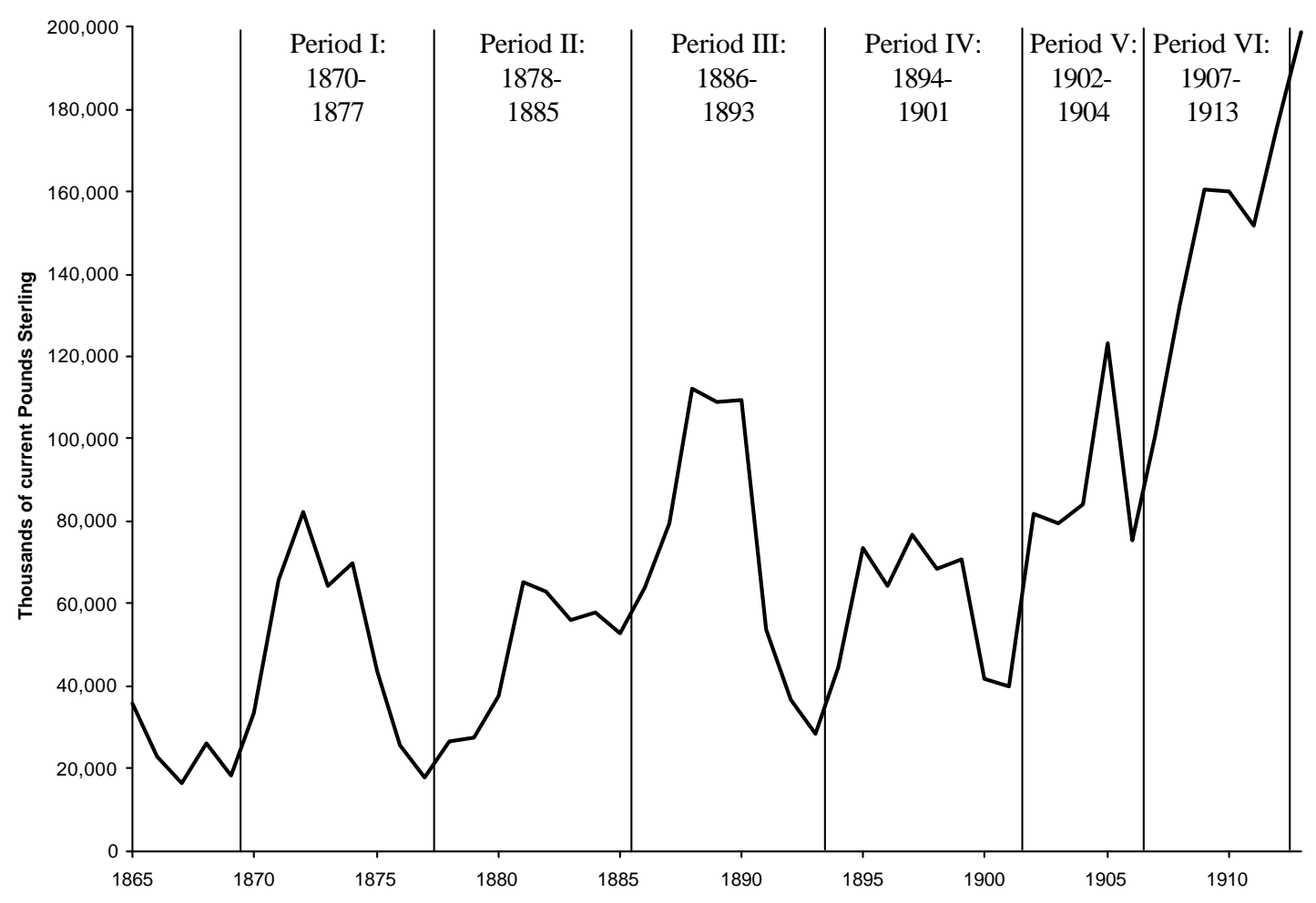

Source: Stone 1999. 
Table 2: Determinants of total British capital flows to 34 countries as a fraction of all British capital exports in each period.

I: $1870-77$

\begin{tabular}{|c|c|c|c|c|c|}
\hline GDP per capita & $\begin{array}{c}0.0000200 \\
(1.97)^{*}\end{array}$ & $\begin{array}{l}0.000193 \\
(1.25)\end{array}$ & $\begin{array}{l}0.0000331 \\
(4.03)^{* * *}\end{array}$ & $\begin{array}{c}0.0000321 \\
(2.17)^{* *}\end{array}$ & $\begin{array}{l}0.0000322 \\
(3.84)^{* * *}\end{array}$ \\
\hline $\begin{array}{l}\text { Log population } \\
\text { share }{ }^{1}\end{array}$ & & $\begin{array}{c}0.0189 \\
(2.98)^{* * *}\end{array}$ & & $\begin{array}{c}0.0237 \\
(4.45)^{* * *}\end{array}$ & \\
\hline British Colony & & $\begin{array}{l}0.00227 \\
(0.088)\end{array}$ & & $\begin{array}{l}-0.00572 \\
(-0.234)\end{array}$ & \\
\hline Other Colony & & $\begin{array}{l}0.00400 \\
(0.155)\end{array}$ & & $\begin{array}{l}-0.0174 \\
(-0.671)\end{array}$ & \\
\hline $\begin{array}{l}\text { Fraction of period } \\
\text { on Gold Standard }\end{array}$ & & $\begin{array}{l}-0.0148 \\
(-0.701)\end{array}$ & & $\begin{array}{l}-0.00126 \\
(-0.062)\end{array}$ & \\
\hline $\begin{array}{l}\text { Import duties } \\
\text { over imports }\end{array}$ & & $\begin{array}{l}0.00231 \\
(2.12)^{* *}\end{array}$ & & $\begin{array}{c}0.000240 \\
(0.262)\end{array}$ & \\
\hline $\begin{array}{l}\text { L agged change in } \\
\text { Terms of Trade }^{2}\end{array}$ & & $\begin{array}{l}0.000257 \\
(1.31)\end{array}$ & & $\begin{array}{l}-0.000128 \\
(-0.421)\end{array}$ & \\
\hline Transport costs 3 & & $\begin{array}{l}-0.00307 \\
(-1.12)\end{array}$ & & $\begin{array}{l}-0.00369 \\
(-1.13)\end{array}$ & \\
\hline $\begin{array}{l}\text { Population } \\
\text { Growth Rate }\end{array}$ & & $\begin{array}{c}-0.000865 \\
(-0.227)\end{array}$ & & $\begin{array}{l}0.00441 \\
(0.673)\end{array}$ & \\
\hline Net immigration & & $\begin{array}{l}0.0120 \\
(1.94)^{*}\end{array}$ & & $\begin{array}{c}0.0137 \\
(2.43) * *\end{array}$ & \\
\hline $\begin{array}{l}\text { Fraction of exports based } \\
\text { on primary products }\end{array}$ & & $\begin{array}{l}0.0327 \\
(0.558)\end{array}$ & & $\begin{array}{c}0.142 \\
(2.39)^{* *}\end{array}$ & \\
\hline U rbanization ${ }^{4}$ & & $\begin{array}{l}-0.101 \\
(-0.057)\end{array}$ & & $\begin{array}{l}0.0193 \\
(0.126)\end{array}$ & \\
\hline $\begin{array}{l}\text { Fraction of pop. < age } 15 \\
\text { enrolled in primary school }\end{array}$ & & $\begin{array}{c}0.00000855 \\
(1.08)\end{array}$ & & $\begin{array}{l}0.00000884 \\
(1.08)\end{array}$ & \\
\hline Constant & $\begin{array}{l}-0.00481 \\
(0.328)\end{array}$ & $\begin{array}{l}-0.0438 \\
(-0.771)\end{array}$ & $\begin{array}{l}-0.0162 \\
(-1.18)\end{array}$ & $\begin{array}{c}-0.147 \\
(-2.57)^{* *}\end{array}$ & $\begin{array}{l}-0.0182 \\
(-1.24)\end{array}$ \\
\hline $\begin{array}{l}\mathrm{N} \\
\mathrm{R}^{2} \\
\text { A djusted } \mathrm{R}^{2}\end{array}$ & $\begin{array}{c}34 \\
0.108 \\
0.0803\end{array}$ & $\begin{array}{c}34 \\
0.641 \\
0.407\end{array}$ & $\begin{array}{c}34 \\
0.337 \\
0.316\end{array}$ & $\begin{array}{c}34 \\
0.736 \\
0.564\end{array}$ & $\begin{array}{c}34 \\
0.316 \\
0.295\end{array}$ \\
\hline
\end{tabular}

III: 1886-93

\begin{tabular}{|c|c|c|}
\hline $\begin{array}{c}0.0000430 \\
(2.50)^{* *}\end{array}$ & $\begin{array}{c}0.0000196 \\
(2.24)^{* *}\end{array}$ & $\begin{array}{c}0.000022 \\
(1.21)\end{array}$ \\
\hline $\begin{array}{c}0.0216 \\
(4.21)^{* * *}\end{array}$ & & $\begin{array}{c}0.0245 \\
(4.63)^{* * *}\end{array}$ \\
\hline $\begin{array}{l}-0.0172 \\
(-0.768)\end{array}$ & & $\begin{array}{l}0.0259 \\
(1.10)\end{array}$ \\
\hline $\begin{array}{l}-0.0147 \\
(-0.509)\end{array}$ & & $\begin{array}{c}0.000146 \\
(0.005)\end{array}$ \\
\hline $\begin{array}{l}-0.0161 \\
(-0.667)\end{array}$ & & $\begin{array}{l}0.0116 \\
(0.569)\end{array}$ \\
\hline $\begin{array}{c}-0.0000269 \\
(-0.029)\end{array}$ & & $\begin{array}{c}0.000161 \\
(0.195)\end{array}$ \\
\hline $\begin{array}{c}-0.0000580 \\
(-0.143)\end{array}$ & & $\begin{array}{c}0.000193 \\
(0.518)\end{array}$ \\
\hline $\begin{array}{c}-0.00814 \\
(-1.55)\end{array}$ & & $\begin{array}{r}-0.00140 \\
(-0.287)\end{array}$ \\
\hline $\begin{array}{c}0.00690 \\
(1.18)\end{array}$ & & $\begin{array}{r}-0.00771 \\
(-0.718)\end{array}$ \\
\hline $\begin{array}{c}0.0133 \\
(2.32)^{* *}\end{array}$ & & $\begin{array}{c}0.00523 \\
(1.10)\end{array}$ \\
\hline $\begin{array}{c}0.154 \\
(2.40) * *\end{array}$ & & $\begin{array}{c}0.129 \\
(2.06)^{*}\end{array}$ \\
\hline $\begin{array}{l}-0.0738 \\
(-0.472)\end{array}$ & & $\begin{array}{c}0.110 \\
(0.632)\end{array}$ \\
\hline $\begin{array}{c}0.00000541 \\
(0.576)\end{array}$ & & $\begin{array}{r}0.0000028 \\
(0.310)\end{array}$ \\
\hline $\begin{array}{c}-0.148 \\
(-2.32)^{* *}\end{array}$ & $\begin{array}{c}-0.00166 \\
(-0.103)\end{array}$ & $\begin{array}{c}-0.133 \\
(-2.22)^{* *}\end{array}$ \\
\hline $\begin{array}{c}34 \\
0.737 \\
0.566\end{array}$ & $\begin{array}{c}34 \\
0.136 \\
0.109\end{array}$ & $\begin{array}{c}34 \\
0.688 \\
0.485\end{array}$ \\
\hline
\end{tabular}

\section{V: $1902-06$}

VI: $1907-13$

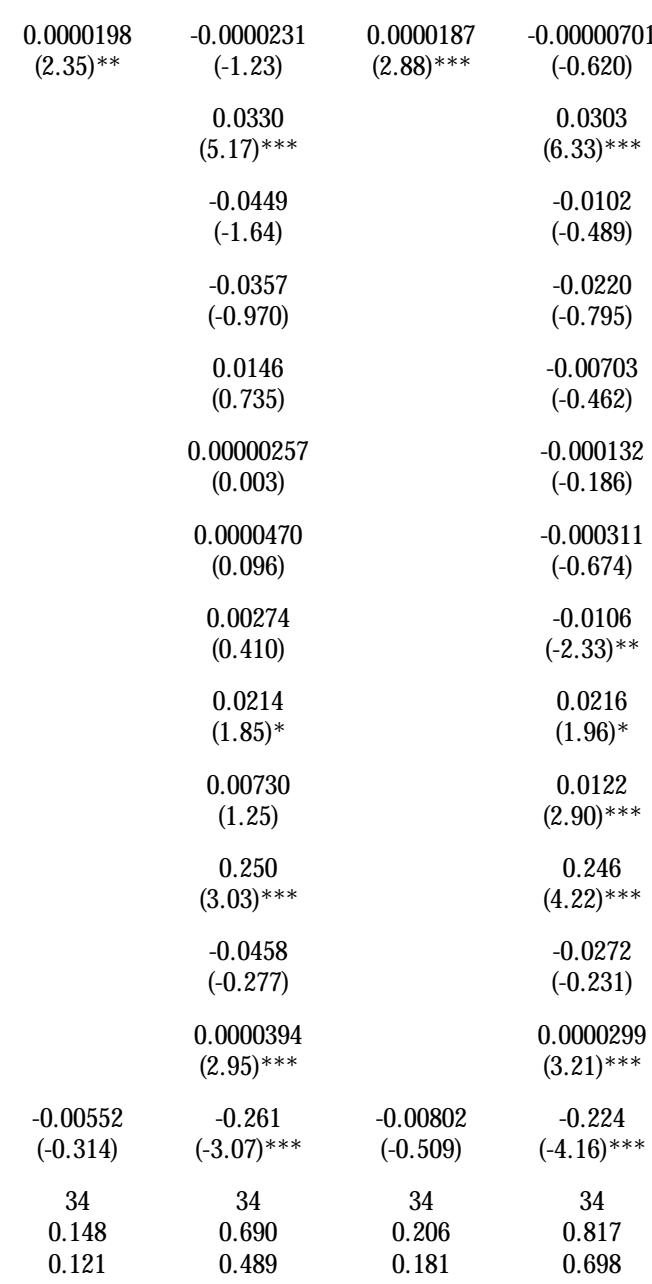

T-statistics are shown in parentheses. * Significant at the $10 \%$ level, $* *$ significant at the $5 \%$ level, ${ }^{* * *}$ significant at the $1 \%$ level. ${ }^{1}$ Population share is defined as the population of destination country as a

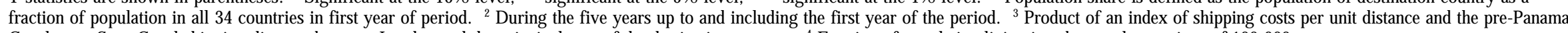
Canal, post-Suez Canal shipping distance between L ondon and the principal port of the destination country. ${ }^{4}$ Fraction of population living in urban agglomerations of 100,000 or more. 
Table 3: Percentage of British capital exports to 34 countries, by recipient sector

Public Sector Private Sector

$\begin{array}{llll}\text { Period I } & 1870-1877 & 55.4 \% & 44.6 \% \\ \text { Period II } & 1878-1885 & 42.3 \% & 57.7 \% \\ \text { Period III } & 1886-1893 & 33.0 \% & 67.0 \% \\ \text { Period IV } & 1894-1901 & 39.0 \% & 61.0 \% \\ \text { Period V } & 1902-1906 & 29.6 \% & 70.4 \% \\ \text { Period VI } & 1907-1913 & 28.1 \% & 71.9 \%\end{array}$

Source: Stone 1999. 
Table 4: Determinants of British capital flows to private sector recipients in 34 countries as a fraction of total British capital exports to private sector recipients in each period.

\section{I: $\mathbf{1 8 7 0 - 7 7}$}

GDP per capita

Log population

share

British Colony

Other Colony

Fraction of period on Gold Standard

Import duties

over imports

Lagged change in

Terms of Trade ${ }^{2}$

Transportation costs ${ }^{3}$

Population

Growth Rate

$\mathrm{N}$ et immigration

Fraction of exports based

on primary products

U rbanization ${ }^{4}$

Fraction of pop < age 15 enrolled in primary schoo

Constant

\begin{tabular}{|c|c|c|c|c|}
\hline \multirow[t]{13}{*}{$\begin{array}{c}0.0000323 \\
(1.72)^{*}\end{array}$} & $\begin{array}{c}0.0000209 \\
(0.746)\end{array}$ & $\begin{array}{c}0.0000259 \\
(2.01)^{*}\end{array}$ & $\begin{array}{c}0.0000127 \\
(0.646)\end{array}$ & $\begin{array}{c}0.00003 \\
(2.75)^{* * *}\end{array}$ \\
\hline & $\begin{array}{c}0.0378 \\
(3.27)^{* * *}\end{array}$ & & $\begin{array}{c}0.0376 \\
(5.32)^{* * *}\end{array}$ & \\
\hline & $\begin{array}{l}-0.0358 \\
(-0.760)\end{array}$ & & $\begin{array}{l}-0.0274 \\
(-0.845)\end{array}$ & \\
\hline & $\begin{array}{l}0.0270 \\
(0.575)\end{array}$ & & $\begin{array}{l}-0.0120 \\
(-0.347)\end{array}$ & \\
\hline & $\begin{array}{l}-0.0166 \\
(-0.434)\end{array}$ & & $\begin{array}{c}-0.00344 \\
(-0.128)\end{array}$ & \\
\hline & $\begin{array}{c}0.00333 \\
(1.69)\end{array}$ & & $\begin{array}{c}0.00145 \\
(1.19)\end{array}$ & \\
\hline & $\begin{array}{c}0.000238 \\
(0.664)\end{array}$ & & $\begin{array}{c}-0.000622 \\
(-1.54)\end{array}$ & \\
\hline & $\begin{array}{l}-0.00398 \\
(-0.803)\end{array}$ & & $\begin{array}{c}-0.00712 \\
(-1.64)\end{array}$ & \\
\hline & $\begin{array}{c}0.00565 \\
(0.815)\end{array}$ & & $\begin{array}{l}0.0109 \\
(1.26)\end{array}$ & \\
\hline & $\begin{array}{l}0.0226 \\
(2.02)^{*}\end{array}$ & & $\begin{array}{c}0.0247 \\
(3.30)^{* * *}\end{array}$ & \\
\hline & $\begin{array}{c}0.186 \\
(1.75)^{*}\end{array}$ & & $\begin{array}{c}0.186 \\
(2.36)^{* *}\end{array}$ & \\
\hline & $\begin{array}{l}0.0770 \\
(0.242)\end{array}$ & & $\begin{array}{l}-0.0277 \\
(-0.136)\end{array}$ & \\
\hline & $\begin{array}{c}0.0000293 \\
(2.04)^{*}\end{array}$ & & $\begin{array}{c}0.0000235 \\
(2.17)^{* *}\end{array}$ & \\
\hline $\begin{array}{l}-0.0103 \\
(-0.385)\end{array}$ & $\begin{array}{c}-0.236 \\
(-2.29)^{* *}\end{array}$ & $\begin{array}{c}-0.00628 \\
(-0.292)\end{array}$ & $\begin{array}{c}-0.188 \\
(-2.47)^{* *}\end{array}$ & $\begin{array}{l}-0.0149 \\
(-0.778)\end{array}$ \\
\hline $\begin{array}{c}34 \\
0.0867\end{array}$ & $\begin{array}{c}34 \\
0.636\end{array}$ & $\begin{array}{c}34 \\
0.112\end{array}$ & $\begin{array}{c}34 \\
0.746\end{array}$ & $\begin{array}{c}34 \\
0.191\end{array}$ \\
\hline
\end{tabular}

\section{III: $1886-93$}

$(1.28)$

0.0301

$(4.89)^{* * *}$

$-0.0427$

$(-1.59)$

$-0.00355$

$(-0.102)$

$-0.00218$

$(-0.075)$

0.000535

(0.487)

0.0000381

$(0.079)$

$-0.00940$

$(-1.49)$

0.00853

(1.21)

0.0202

$(2.94) * * *$

0.204
$(2.64)^{* *}$

$-0.122$

$(-0.647)$

0.0000175

(1.56)

-0.194
$(-2.55)^{* *}$

$(-2.55)^{* *}$

34
0.737
IV: 1894-1901

$0.0000303 \quad 0.0000351$

$(3.31)^{* * *}$

(1.63)

0.0261
$(4.34)^{* * *}$

0.0118

$(0.442)$

0.0103

$(0.294)$

0.00212

(0.091)

0.000201

(0.213)

0.000190

$(0.446)$

$-0.00641$

$(-1.16)$

0.00263

(0.215)

0.00919

(1.70)

0.163

$(2.29)^{* *}$

0.0532

$(0.268)$

0.00000590

(0.573)

$-0.175$

$(-2.57)^{*}$

$\begin{array}{cc}34 & 34 \\ 0.255 & 0.682\end{array}$

\section{V: $1902-06$}

$0.0000307 \quad 0.00000400$

0.00000400

$(0.156)$
0.0361

$(4.17)^{* * *}$

$-0.0381$

$(-1.02)$

$-0.00564$

$(-0.113)$

$-0.00263$

$(-0.098)$

$-0.0000102$

$(-0.009)$

0.000583

$(0.881)$

$-0.0167$

$(-1.85)^{*}$

0.0120

$(0.769)$

0.0188

$(2.37) * *$

0.276

$(2.46)^{* *}$
-0.107

$(-0.478)$

0.0000282

(1.55)

-0.228
$(-1.98)^{*}$

34
0.663

$(-1.13)$

34
0.210
VI: 1907-13

$0.0000222-0.00000103$ $\begin{array}{cc}(2.86) * * * & -0.0000103 \\ & (-0.068)\end{array}$

0.0343

$(5.33)^{* * *}$

$-0.0325$

$(-1.16)$

$-0.0260$

$(-0.699)$

$-0.00835$

$(-0.408)$

$-0.000470$

$(-0.493)$

$-0.000386$

$(-0.623)$

$-0.0146$

$(-2.39)^{* *}$

0.0229

(1.54)

0.0172

$(3.04)^{* * *}$

0.271

$(3.44)^{* * *}$

$-0.139$

$(-0.878)$

0.0000301

$(2.41)^{* *}$

-0.224
$(-3.09) * * *$

$(-0.799)$

$(-3.09)^{* * *}$

$\begin{array}{cc}34 & 34 \\ 0.204 & 0.767\end{array}$

T-statistics are shown in parentheses. * Significant at the $10 \%$ level, ${ }^{* *}$ significant at the $5 \%$ level, ${ }^{* * *}$ significant at the $1 \%$ level. ${ }^{1}$ Population share is defined as the population of destination country as a fraction of population in all 34 countries in first year of period. ${ }^{2}$ D uring the five years up to and including the first year of the period. ${ }^{3}$ Product of an index of shipping costs per unit distance and the pre-Panama Canal, post-Suez Canal shipping distance between London and the principal port of the destination country. ${ }^{4}$ Fraction of population living in urban agglomerations of 100,000 or more 
Table 5: Determinants of British capital flows to government recipients in 34 countries as a fraction of total British capital exports to government recipients in each period.

I: $1870-77$

\begin{tabular}{|c|c|c|c|c|}
\hline GDP per capita & $\begin{array}{c}0.0000101 \\
(1.21)\end{array}$ & $\begin{array}{c}0.0000180 \\
(1.12)\end{array}$ & $\begin{array}{l}0.0000430 \\
(4.45)^{* * *}\end{array}$ & $\begin{array}{l}0.0000586 \\
(2.81)^{* *}\end{array}$ \\
\hline $\begin{array}{l}\text { Log population } \\
\text { share } \mathrm{e}^{1}\end{array}$ & & $\begin{array}{l}0.00373 \\
(0.563)\end{array}$ & & $\begin{array}{l}0.00471 \\
(0.626)\end{array}$ \\
\hline British Colony & & $\begin{array}{l}0.0330 \\
(1.22)\end{array}$ & & $\begin{array}{l}0.0238 \\
(0.693)\end{array}$ \\
\hline Other Colony & & $\begin{array}{l}-0.0145 \\
(-0.539)\end{array}$ & & $\begin{array}{l}-0.0249 \\
(-0.680)\end{array}$ \\
\hline $\begin{array}{l}\text { Fraction of period } \\
\text { on Gold Standard }\end{array}$ & & $\begin{array}{l}-0.0133 \\
(-0.606)\end{array}$ & & $\begin{array}{l}0.00172 \\
(0.061)\end{array}$ \\
\hline $\begin{array}{l}\text { Import duties } \\
\text { over imports }\end{array}$ & & $\begin{array}{l}0.00149 \\
(1.31)\end{array}$ & & $\begin{array}{c}-0.00141 \\
(-1.09)\end{array}$ \\
\hline $\begin{array}{l}\text { L agged change in } \\
\text { Terms of Trade }^{2}\end{array}$ & & $\begin{array}{c}0.000273 \\
(1.33)\end{array}$ & & $\begin{array}{l}0.000547 \\
(1.27)\end{array}$ \\
\hline Transportation costs ${ }^{3}$ & & $\begin{array}{l}-0.00233 \\
(-0.818)\end{array}$ & & $\begin{array}{c}0.000990 \\
(0.215)\end{array}$ \\
\hline $\begin{array}{l}\text { Population } \\
\text { Growth Rate }\end{array}$ & & $\begin{array}{c}-0.00611 \\
(-1.54)\end{array}$ & & $\begin{array}{l}-0.00453 \\
(-0.491)\end{array}$ \\
\hline N et immigration & & $\begin{array}{l}0.00338 \\
(0.525)\end{array}$ & & $\begin{array}{l}-0.00128 \\
(-0.161)\end{array}$ \\
\hline $\begin{array}{l}\text { Fraction of exports based } \\
\text { on primary products }\end{array}$ & & $\begin{array}{l}-0.0907 \\
(-1.49)\end{array}$ & & $\begin{array}{l}0.0822 \\
(0.983)\end{array}$ \\
\hline U rbanization ${ }^{4}$ & & $\begin{array}{l}-0.0801 \\
(-0.439)\end{array}$ & & $\begin{array}{l}0.0835 \\
(0.386)\end{array}$ \\
\hline $\begin{array}{l}\text { Fraction of pop. < age } 15 \\
\text { enrolled in primary school }\end{array}$ & & $\begin{array}{c}-0.00000812 \\
(-0.987)\end{array}$ & & $\begin{array}{c}-0.0000113 \\
(-0.977)\end{array}$ \\
\hline Constant & $\begin{array}{l}0.0170 \\
(1.40)\end{array}$ & $\begin{array}{c}0.111 \\
(1.87)^{*}\end{array}$ & $\begin{array}{l}-0.0298 \\
(-1.85)^{*}\end{array}$ & $\begin{array}{l}-0.0915 \\
(-1.13)\end{array}$ \\
\hline $\begin{array}{l}N \\
R^{2}\end{array}$ & $\begin{array}{c}34 \\
0.0434\end{array}$ & $\begin{array}{c}34 \\
0.389\end{array}$ & $\begin{array}{c}34 \\
0.382\end{array}$ & $\begin{array}{c}34 \\
0.645\end{array}$ \\
\hline
\end{tabular}

III: $1886-93$

$0.0000366 \quad 0.0000768$ $(3.44)^{* * *}$

$(2.90) * * *$

0.00430

(0.544)

0.0346

(1.01)

$-0.0374$

$(-0.841)$

$-0.0445$

$(-1.20)$

$-0.00117$

$(-0.830)$

$-0.000253$

$(-0.407)$

$-0.00560$

$(-0.693)$

0.00358

$(0.397)$

$-0.000676$

$(-0.077)$

0.0540

$(0.546)$

0.0232

$(0.096)$

$-0.0000192$

$(-1.33)$

$-0.0247$

$(-1.32)$

34
0.270

$-0.0527$

$(-0.540)$

34
0.590
IV : 1894-1901

$0.00000283 \quad 0.00000380$

$0.262)$
$(0.2)$

(0.166)

0.0218
$(3.41)^{* * *}$

0.0479

(1.69)

$-0.0157$

$(-0.423)$

0.0265

(1.07)

0.0000987

$(0.098)$

0.000199

(0.440)

0.00645

(1.10)

$-0.0239$

$(-1.84)^{*}$

$-0.000981$

$(-0.171)$

0.0754

(0.997)

0.199

(0.945)

$-0.00000206$

$(-0.188)$

0.0249
$(1.25)$

$-0.0670$

$(-0.925)$

34
0.002

34
0.655

V: $1902-06$ $-0.0000875$ $(-3.11)^{* * *}$

0.0256

$(2.69)^{* *}$

$-0.0611$

$(-1.49)$

$-0.107$

$(-1.95)^{*}$

0.0553

$(1.87)^{*}$

0.0000329

$(0.025)$

$-0.00122$

$(-1.68)$

0.0489

$(4.91)^{* * *}$

0.0436

$(2.53)^{* *}$

$-0.0199$

$(-2.29)^{* *}$

0.188

(1.52)

0.0998

$(0.404)$

0.0000662

(3.31)***

0.0402

-0.337
$(-2.66) * *$

34
0.007

$(-2.66)^{* *}$

34
0.656

0.00000981

(1.65)

$(-1.71)$

0.0200

$(3.63)^{* * *}$

0.0468

(1.95)*

$-0.0117$

$(-0.367)$

$-0.00367$

$(-0.209)$

0.000731

$(0.895)$

$-0.000119$

$(-0.224)$

$-0.000240$

$(-0.046)$

0.0184

(1.45)

$-0.000588$

$(-0.121)$

0.185

$(2.74)^{* *}$
0.259

(1.91)*

0.0000293

$0.00982 \quad-0.225$

$(0.685) \quad(-3.63)^{* * *}$

T-statistics are shown in parentheses, * Significant at the $10 \%$ level, $* *$ significant at the $5 \%$ level, $* * *$ significant at the $1 \%$ level. ${ }^{1}$ Population share is defined as the population of destination country as a fraction of population in all 34 countries in first year of period. 2 During the five years up to and including the first year of the period. 3 Product of an index of shipping costs per unit distance and the pre-Panama

Canal, post-Suez Canal shipping distance between L ondon and the principal port of the destination country. ${ }^{4}$ Fraction of population living in urban agglomerations of 100,000 or more 
Table 6: Evidence that investment in the public sector "crowded in" investment in the private sector, but not vice-versa

\begin{tabular}{|c|c|c|c|c|}
\hline Regressand: & \multicolumn{2}{|c|}{$\begin{array}{l}\text { Current investment } \\
\text { in private sector }\end{array}$} & \multicolumn{2}{|c|}{$\begin{array}{l}\text { Current Investment } \\
\text { in public sector }\end{array}$} \\
\hline Estimator: & $\begin{array}{l}\text { Panel } \\
\text { Fixed } \\
\text { Effects }\end{array}$ & $\begin{array}{l}\text { Anderson- } \\
\text { Hsiao }\end{array}$ & $\begin{array}{l}\text { Panel } \\
\text { Fixed } \\
\text { Effects }\end{array}$ & $\begin{array}{l}\text { Anderson- } \\
\text { Hsiao }\end{array}$ \\
\hline \multicolumn{5}{|l|}{ Regressor: } \\
\hline $\begin{array}{l}\text { L agged investment } \\
\text { in private sector }\end{array}$ & $\begin{array}{c}-0.2393 \\
(-3.670)^{* * *}\end{array}$ & $\begin{array}{c}-0.6698 \\
(-4.415)^{* * *}\end{array}$ & $\begin{array}{l}0.05996 \\
(1.465)\end{array}$ & $\begin{array}{l}0.05299 \\
(1.023)\end{array}$ \\
\hline $\begin{array}{l}\text { L agged investment } \\
\text { in public sector }\end{array}$ & $\begin{array}{c}0.1587 \\
(1.721)^{*}\end{array}$ & $\begin{array}{c}0.4817 \\
(3.852)^{* * *}\end{array}$ & $\begin{array}{c}-0.3661 \\
(-6.320)^{* * *}\end{array}$ & $\begin{array}{l}0.01493 \\
(0.100)\end{array}$ \\
\hline $\mathrm{N}$ & 272 & 238 & 272 & 238 \\
\hline
\end{tabular}




\section{Table 7: Determinants of the R elative Equipment Price Ratio ${ }^{1}$ in Eight C ountries}

\begin{tabular}{|c|c|c|c|c|c|c|}
\hline Period & I: 1870-77 & II: 1878-85 & III: 1886-93 & IV: 1894-1901 & V: $1902-06$ & VI: $1907-13$ \\
\hline $\begin{array}{l}\text { Transportation } \\
\text { Costs }\end{array}$ & $\begin{array}{c}30.76 \\
(3.437)^{*}\end{array}$ & $\begin{array}{c}23.57 \\
(6.548)^{* *}\end{array}$ & $\begin{array}{c}29.90 \\
(3.753)^{*}\end{array}$ & $\begin{array}{c}12.81 \\
(2.258)\end{array}$ & $\begin{array}{c}9.546 \\
(1.034)\end{array}$ & $\begin{array}{c}6.401 \\
(0.715)\end{array}$ \\
\hline $\begin{array}{l}\text { Fraction of pop. } \\
<\text { age } 15 \text { enrolled } \\
\text { in primary school }\end{array}$ & $\begin{array}{c}-0.05298 \\
(-1.274)\end{array}$ & $\begin{array}{l}-0.05019 \\
(-3.473)^{*}\end{array}$ & $\begin{array}{c}-0.03710 \\
(-1.951)\end{array}$ & $\begin{array}{c}-0.03818 \\
(-2.138)\end{array}$ & $\begin{array}{l}-0.04328 \\
(-3.013)^{*}\end{array}$ & $\begin{array}{l}-0.04700 \\
(-2.997)^{*}\end{array}$ \\
\hline GDP per capita & $\begin{array}{l}0.1540 \\
(0.879)\end{array}$ & $\begin{array}{l}0.09896 \\
(2.046)\end{array}$ & $\begin{array}{l}0.08548 \\
(1.046)\end{array}$ & $\begin{array}{l}0.03249 \\
(0.647)\end{array}$ & $\begin{array}{c}0.003178 \\
(0.113)\end{array}$ & $\begin{array}{c}0.004616 \\
(0.203)\end{array}$ \\
\hline $\begin{array}{l}\text { Import duties } \\
\text { over imports }\end{array}$ & $\begin{array}{c}-4.867 \\
(-1.916)\end{array}$ & $\begin{array}{c}-1.722 \\
(-1.510)\end{array}$ & $\begin{array}{c}-4.365 \\
(-1.472)\end{array}$ & $\begin{array}{l}-0.3117 \\
(-0.109)\end{array}$ & $\begin{array}{c}1.173 \\
(0.390)\end{array}$ & $\begin{array}{l}0.8017 \\
(0.240)\end{array}$ \\
\hline Urbanization & $\begin{array}{c}-1580 \\
(-0.896)\end{array}$ & $\begin{array}{c}-1132 \\
(-2.466)\end{array}$ & $\begin{array}{c}-790.6 \\
(-1.150)\end{array}$ & $\begin{array}{c}-743.4 \\
(-1.094)\end{array}$ & $\begin{array}{c}-213.1 \\
(-0.525)\end{array}$ & $\begin{array}{c}-116.8 \\
(-0.298)\end{array}$ \\
\hline Constant & $\begin{array}{c}124.3 \\
(1.255)\end{array}$ & $\begin{array}{c}160.2 \\
(4.256)^{*}\end{array}$ & $\begin{array}{c}161.4 \\
(2.988)^{*}\end{array}$ & $\begin{array}{c}266.1 \\
(5.117)^{* *}\end{array}$ & $\begin{array}{c}286.0 \\
(5.963)^{* *}\end{array}$ & $\begin{array}{c}290.7 \\
(5.870)^{* *}\end{array}$ \\
\hline $\begin{array}{l}N \\
R^{2}\end{array}$ & $\begin{array}{c}8 \\
0.9748\end{array}$ & $\begin{array}{c}8 \\
0.9890\end{array}$ & $\begin{array}{c}8 \\
0.9719\end{array}$ & $\begin{array}{c}8 \\
0.9569\end{array}$ & $\begin{array}{c}8 \\
0.9508\end{array}$ & $\begin{array}{c}8 \\
0.9344\end{array}$ \\
\hline
\end{tabular}

T-statistics in parentheses. * Significant at the $10 \%$ level. $* *$ Significant at the $5 \%$ level. ${ }^{1}$ The Relative Equipment Price Ratio is defined as $\left(P_{e, j} / P_{c, j}\right) /\left(P_{e, G B} / P_{c, G B}\right)$, where $P_{e, j}$ denotes absolute price level of equipment in country $j, P_{c, j}$ denotes absolute price level of consumer goods in country $j$, and GB stands for Great Britain. 


\section{Appendix: The Data}

All data used come from a novel database constructed for the purposes of this study, often from primary sources held by the Harvard College Library. The construction of each variable and its sources will be discussed in turn.

\section{British Capital Exports}

Original gross capital flow numbers for A rgentina, A ustralia, A ustria-H ungary, Brazil, Canada, Chile, China, Cuba, Egypt, France, Germany, Greece, India, Italy, Japan, M exico, New Zealand, Peru, Russia, Spain, Turkey, United States and U ruguay come from Irving Stone, 1999, The Global Export of Capital from Great Britain, 1865-1914, St. M artin's Press, $\mathrm{N}$ ew Y ork. A dditional figures for Burma, Ceylon, Colombia, Denmark, Indonesia, N orway, Philippines, Portugal, Serbia, Sweden, and Thailand were kindly provided by Professor Stone. Stone's division of the flows according to whether they were received by governments or by the private sector is maintained unchanged.

In the above, "Egypt" refers to the lands under rule of the Egyptian Pasha before British occupation, and thereafter to the lands of the de facto British protectorate, although it was officially part of the Ottoman Empire during the entire period in question. "Germany" refers to the lands of the Second German Reich. "India" refers to the British colonial boundaries for India, omitting lands contained within present-day Burma/M yanmar which we treat as a distinct recipient of capital. "Turkey" refers to the Ottoman Empire without A Ibania, Rumania, Serbia, Greece, Bulgaria, or Egypt. "Indonesia" refers to the Dutch East Indies and corresponds closely to the boundaries of the modern Republic of Indonesia.

"N orway" refers to the area of land over which the N orwegian government retained limited autonomy during Swedish rule before 1905, and to the state of N orway thereafter. "Thailand" refers to the Kingdom of Siam.

Flows are converted first into real Pounds Sterling using the deflator found in J ohn M cC usker, 1992, How Much Is That in Real Money? A merican A ntiquarian Society, Worcester, $M$ ass. The left-hand side variable is then constructed by calculating the cumulative flow to each country during each period and dividing by the cumulative flow to all 34 countries during the same period.

Our use of prewar British capital flows rather than stocks sidesteps a significant literature criticizing the accuracy of the stock figures. The accuracy of figures on flows and their geographical distribution has survived decades of scrutiny essentially unsullied (D. C. M. Platt, 1986, Britain's O verseas Investment on the Eve of the First World War: The U se and Abuse of Numbers, M acM illan, London, p. 100). Why this difference? It is one thing to say that capital flowed from Great Britain to a given country-a well-documented fact. It is another thing to say that the investments thereby purchased were held by Great Britain, thus representing a stock of 'British' capital. In fact, the nationality of those who purchased securities in L ondon during this period is very poorly documented. By eschewing stocks in favor of flows we avoid the issue.

\section{GDP per Capita}


The units on this variable are 1990 US dollars per inhabitant of any age. The regressor used is GDP per capita in the first year of each period. GDP per capita estimates for A ustralia, Brazil, Canada, China, D enmark, France, Germany, India, Indonesia, Italy, Japan, M exico, New Zealand, Norway, Portugal, Russia, Spain, Sweden, Thailand, and the United States come from A ngus M addison, 1995, M onitoring the World Economy, 18201992, OECD, Paris. M issing years are estimated by geometric interpolation.

Estimates for Egypt after 1900 and Turkey in 1913 come from M addison. Before this date it is assumed that GDP per capita grew at the same year-on-year rate as did estimates of Egyptian and Turkish real wages from J effrey Williamson, 2000, "Real wages and relative factor prices around the M editerranean, 1500-1940," in Sevket Pamuk and J effrey G. Williamson, eds. The Mediterranean Response to Globalization B efore 1950, Routledge, New Y ork.

Data for Greece are estimated by projecting M addison's (op. cit.) 1913 figure backwards, assuming the growth rate found in James Foreman-Peck and Pedro Lains, 2000, "European Economic Development: The Core and the Southern Periphery, 1870-1910," in Sevket Pamuk and J effrey G. Williamson, eds., The Mediterranean Response to Globalization Before 1950, Routledge, N ew Y ork.

Data for A rgentina after 1890 come from M addison op. cit. B efore this date, GDP per capita is assumed to grow at the same year-on-year rate as the estimates of A rgentine real wages found in J effrey G. Williamson, 1995, "The Evolution of Global Labor M arkets since 1830: Background Evidence and Hypotheses," Explorations in Economic History, 32:141196. Data for U ruguay after 1882, and Peru and Chile after 1900, come from M addison op. cit. Before these dates it is assumed that all three grew at the same year-on-year rate as did our estimates of A rgentine GDP per capita.

Estimates for Cuba for 1850 and 1913 are based on estimates of Cuban GDP per capita relative to that of $\mathrm{M}$ exico and Brazil presented in J ohn $\mathrm{H}$. Coatsworth, 1998, "E conomic and Institutional Trajectories in N ineteenth-C entury Latin A merica," in John $\mathrm{H}$. Coatsworth and Alan M. Taylor, eds., Latin America and the World Economy Since 1800, Harvard U niversity Press, Cambridge, Mass. A n unweighted average of the figures implied by Coatsworth's proportion of our estimates for M exico and Brazil is calculated for both years, and the intervening years estimated by geometric interpolation.

Data for Colombia after 1900 come from M addison op. cit. Before this date, it is assumed that that GDP per capita grew at an unweighted average of the growth rates for M exico and Brazil between 1850 and 1900 given in Coatsworth op. cit.

Data for the Philippines and Burma after 1900 come from M addison op. cit. Before this date it is assumed that Philippine GDP per capita grew at the same year-on-year rate as our estimates for Thailand, and that Burmese growth mirrored that of India.

GDP per capita estimates for A ustria-H ungary come from David F. Good, 1994, "The Economic L ag of Central and Eastern Europe: Income Estimators for the Habsburg Successor States, 1870-1910," J ournal of Economic History, 54(4)(December): 69-891. These are converted from 1980 to 1990 dollars using a GDP deflator obtained from the Bureau of E conomic A nalysis of the U nited States D epartment of Commerce (online at http://www. bea. doc. gov/bea/dn/gdplev. htm).

Estimates for Serbia after 1890 come from Foreman-Peck and Lains, op. cit. Before 1890 GDP per capita is assumed to grow at the same year-on-year rate as it did between 1890 and 1913. 
Ceylon presented the most difficult data challenge in this category, as we are not aware of any published figures for GDP in Ceylon during this period. Campbell (Burnham O. Campbell, 1993 "D evelopment Trends: A Comparative A nalysis of the A sian Experience," in Naohiro Ogawa et al., eds., Human Resources in Development along the Asia-Pacific Rim, Oxford U niversity Press, N ew Y ork) has estimated that in 1914, GDP per capita in Ceylon was 1.95 times that of India. B efore 1914, it is assumed that real GDP per capita grew at the same rate as did the ratio of the real value of $B$ ritish colonial revenue from Ceylon to the population of the Island. A full series of annual nominal colonial revenues and population figures come from the 1905 and 1914 editions of the annual Ceylon Blue Book, a statistical publication of the colonial administration in Colombo. Some of these figures were recorded in rupees, and are converted to pounds sterling using conversion rates from Bryan Taylor II, 2000, Encyclopedia of Global Financial Markets, Global Financial Data, L oS Angeles, California (online at http://www. globalfindata.com). The resulting figures are converted to real pounds sterling using the deflator in M cC usker op. cit.

\section{Population Share}

Population Share is calculated by dividing the population of the country in the first year of the period by the total population of all 34 countries in the same year. The regressor used is log of population share in the first year of each period.

A nnual estimates of the population of A rgentina, A ustria-Hungary, Colombia, and Denmark come from Banks, A rthur S. Banks, 1976, Cross-National Time Series, 1815-1973 [Computer File], ICPSR ed. A nn A rbor, M I: Inter-U niversity Consortium for Political and Social Research [producer and distributor]. Estimates for Chile, Indonesia, $\mathrm{N}$ ew Zealand, Peru, the Philippines, Russia and Thailand come from M addison op. cit. Estimates for Greece and Turkey after 1900 also come from M addison op. cit. Before this date we assume that $G$ reek population grew at the year-on-year rate implied by the population figures in B. R. M itchell, 1981, European Historical Statistics, $2^{\text {nd }}$ rev. ed., M acmillan, L ondon. We assume that Turkish population (omitting Egypt) before 1900 grew at the year-on-year rate implied by the figures in Halil Inalcik, ed., 1994, An Economic and Social History of the 0 ttoman Empire, Vol. 2, Cambridge U niversity Press, N ew Y ork, p. 779.

Population estimates for A ustralia, Brazil, Burma, Canada, Cuba, Egypt, France, Germany, India, Italy, Japan, M exico, N orway, Serbia, Spain, and Sweden are from the appropriate volume of M itchell 1998 op. cit.

Estimates for China are from Angus M addison, 1998, Chinese Economic Performance in the Long Run, OECD, Paris. Figures for Ceylon come from Colonial Secretary's Office, 1914, Ceylon Blue Book, H.C. Cottle Government Printer, Colombo. Estimates for Portugal come from A na Bela N unes, 1989, "Portuguese E conomic Growth: 1833-1985," J ournal of European E conomic History, 18(1)(Spring):291-330. Estimates for the U nited States come from Historical Statistics of the U nited States: From Colonial Times to the Present, Basic Books, N ew Y ork, 1976. Data for U ruguay come from Mitchell op. cit.; from J. Wilkie, 1996, Statistical Abstract of Latin America, vol. 32, U CLA Latin A merican Publications, L os A ngeles; and from U ruguay, Bureau of the A merican Republics, W ashington, DC, 1892, p. 92 . 


\section{Colonial Status}

The regressor for British Colony is 1 if the country was a B ritish colony for a majority of the period, and zero otherwise-the regressor for "other colony" is constructed similarly. The year-by-year colonial status of A ustralia, Brazil, Chile, Cuba, Egypt, India, and Uruguay is taken from the Encyclopedia Britannica. For Burma, Indonesia, and Thailand colonial status is taken to be as reported in B. R. M itchell, 1998, International Historical Statistics, Africa, Asia \& O ceania, 3rd ed., St. M artin's Press, N ew Y ork., page xii. For M exico it is as given in B. R. M itchell, 1998, International Historical Statistics, The Americas, 4th ed., St. M artin's Press, N ew Y ork. Serbia is taken to be a colony of the Ottoman E mpire until 1878 and independent thereafter, as described in B. R. M itchell, 1998, International Historical Statistics: Europe 1750-1993, 4th ed., St. M artin's Press, N ew York, page xiii.

China is assigned the status of "British colony" during all of 1870-1913 for the purposes of this study, in light of the special presence of Britain in Shanghai. Canada, Egypt (after 1882) and N ew Zealand are similarly assigned the status of "British colony" for the purposes of this study, though they were not technically colonies. The Philippines are taken to have been a Spanish colony until 1899 and a colony of the U nited States thereafter.

\section{The Gold Standard}

The regressor is calculated as the fraction of years in the period during which the country was on a pure gold standard; an al ternative regressor allowed also a silver or bimetallic standard. A detailed, year-by-year assessment of monetary regime in 28 of our 34 countries during 1870-1914 was kindly provided to the authors by Chris M eissner. These data provided an indication of gold, silver, bimetallic, or paper standard.

M onetary regimes for Cuba, Peru, Serbia, Thailand, and U ruguay are taken to be as reported in Taylor op. cit. The regime for $\mathrm{N}$ ew Zealand is given in J. Ernesto LopezCordova and Chris M eissner, 2000, "Exchange-R ate Regimes and International Trade: Evidence from the Classical Gold Standard Era," Dept. of Economics, U niversity of California at Berkeley, Berkeley, California, Table 4.1.

\section{Import Duties over I mports}

The regressor is calculated as the total government revenue from import duties in the first year of the period, divided by the total value of imports into the country in that year.

Figures for A ustralia, Canada, Denmark, France, Germany, Italy, Norway, Sweden, and the U nited States are given in Kevin H.O'Rourke, 2000, "Tariffs and Growth in the Late 19th Century," The Economic Journal, 110(A pril): 456-83.

Figures for A rgentina 1865-1900 are from the Anuario de la Dirección General de Estadística Correspondiente al Año 1900, vol. 1, Compañía Sud-A mericana de Billetes de Banco, Buenos A ires, 1901, p. 357, while figures for 1910-1913 come from the 1915 edition of the same publication (p. 798 and 815).

Figures for A ustria-H ungary are estimated in D avid F. Good, 1984, The Economic Rise of the Habsburg Empire 1750-1914, University of California Press, Berkeley, p. 227. 
There are transcriptions of primary-source numbers for Brazilian imports, government income, and fraction of government income due to import duties in L aura Randall, 1977, A Comparative Economic History of Latin America: 1500-1914, Volume 3: Brazil, Institute for Latin A merican Studies, Columbia U niversity, N ew Y ork, pp. 219-249.

Figures for Burmese import duty revenue come from the Report on the Administration of British Burma (some years omit the word "British" from the title) printed in Rangoon, for 1891, 1892, 1906, 1907, 1909, and 1910. Burmese imports are given in various editions of the Statistical Abstract Relating to British India, Eyre \& Spottiswoode for HM SO, Presented to both Houses of Parliament by Command of Her M ajesty, London, and Statistics of British India, Part II: Commercial, Director-General of Commercial Intelligence, Calcutta, 1913. $M$ issing years are interpolated geometrically; the 1891 figure is assumed to hold constant on 1870-1891, a period during which British trade policy in the area did not significantly change.

Figures for Ceylon 1902-1912 on import duties and imports come from the 1905 and 1914 editions of the Ceylon Blue Book. The 1902 figure is assumed to hold for 1870-1901 based on Batemen's contemporary report that the same rates seen in 1902 al so prevailed in the years leading up to 1885 (A. E. Batemen, 1885, "Customs Tariffs," J ournal of the Statistical Society of London, 48(4)(December): 617-27).

Figures for Chile are given directly in M arkos J. M amalakis, 1989, Historical Statistics of Chile: Government Services and Public Sector and a Theory of Services, Vol. 6, Greenwood Press, N ew Y ork, p. 206.

The treaties of Nanking (1843) and Tientsin (1858), as well as other similar treaties, limited the Chinese ad valorem tariff rate on imports from essentially all of Europe to $5 \%$. In fact, the treaties (and their revisions in 1870, 1902 and 1922) did not set ad valorem rates but rather absolute nominal duties that, although initially equivalent to a $5 \%$ ad valorem tariff, rapidly declined in effective value as prices rose (C. F. Remer, 1926, The Foreign Trade of China, The Commercial Press Ltd., Shanghai, pp. 171-181). "The average effective rates were often below three percent and were never above four percent even in the years immediately following the revisions" (Y u-K wei Cheng, 1956, Foreign Trade and Industrial Development of China: An Historical and Integrated Analysis through 1948, The U niversity Press, Washington, pp. 8-13). For this reason it is assumed that import-duties-over-imports for China started at $4 \%$ in each revision year and declined at a constant rate to $2.5 \%$ in the year immediately preceding the next revision.

Figures for Colombian customs revenue and imports come from José A ntonio Ocampo, 1997, Historia Económica de Colombia, Presidencia de la República, Imprenta N acional, Bogotá, pp. 187 and 194. It is assumed that the vast majority of customs revenue came from import rather than export taxes, as Ocampo reports.

In Cuba, "On F ebruary 10, 1818, freedom of trade was decreed. But the customs tariffs established in that connection were ferociously protective of Spanish commerce and ships ... with ... tariffs ranging from $20 \%$ to $36 \%$ ad valorem. ... This system lasted through the nineteenth century with occasional changes to increase protection against foreign products" (J ulio Le Riverend, 1967, Economic History of Cuba, Ensayo Book Institute, Havana, p. 177). A benchmark of import duties and imports from 1840 comes from Cuadro Analítico del Comercio, Navegación y Rentas de la Isla de Cuba en el Año de 1840, Imprenta del Comercio, Havana, 1841, pp. 12 and 16, and is assumed to hold constant until 1882. $\checkmark$ arious authors support such an assumption, describing how trade policy changed little until 
the revenue-neutral shift of tariffs away from Spanish goods and towards the produce of other nations began in 1882 (e.g. Fidel G. Pierra, 1896, Spanish Misrule in America, Cuban Delegation in the U nited States, Washington, p. 30 and Enrique José $V$ arona, 1917, Cuba vs. Spain, p. 15). Customhouse revenue in 1895 is quoted from The Cuban Question in Its True Light, 1896, p. 25, and imports for that year from Gonzalo De Quesada, 1905, Cuba, International Bureau of the A merican Republics, Government Printing Office, Washington, p. 154. Import duties and imports for 1905-1914 come from Comercio Exterior, Segundo Semestre de 1914, Sección de Estadística, Secretaria de Hacienda, República de Cuba, Havana, 1915, pp. XII-XIV. The import-duties-over-imports figure for 1895 is assumed to hold until the Treaty of Paris in 1898, from which time through 1904 the 1905 figure is assumed to hold.

Data for Egypt on 1885-1908 come from the Statistical Yearbook of Egypt for 1909, National Printing Department, Cairo, pp. 83 and 103, and the Annuaire Statistique de I'E gypte 1914, Imprimerie Nationale, Cairo, pp. 303 and 410. Figures for 1909-1913 are estimated by assuming that import duties grew after 1908 at the same year-on-year rate as did total customs revenue. The 1885 figure is assumed to hold on 1882-1884. Before the 1882 B ritish occupation, the figure for Turkey is used.

Figures on import duties and imports for Greece, 1887-1897 come from Commerce de la G rèce avec les Pays Étrangers pendant l'Année 1900, Imprimerie Nationale, A thens, 1901, p. 5, and figures for 1898-1910 from Statistique du Commerce Special de la G rèce avec les Pays Étrangers pendant I'Année 1909, Bureau de Statistique du M inistère des Finances, Imprimerie Nationale, A thens, 1911, pp. 2 and 40 (as well as the same pages of the 1912 edition). A single datapoint for 1868 is available in Demetrius Bikelas, 1868, "Statistics of the Kingdom of Greece," J ournal of the Royal Statistical Society, 31(3)(September): 265-98. When, then, during the period 1869-1886 did Greece make the transition from low tariffs to protective tariffs? Writing in 1878, N ewmarch divides the countries of the world into five groups, according to "the degree in which the Tariffs of the respective groups are hostile to the admission of exports sent from the U nited Kingdom" (William N ewmarch, 1878, "On the Progress of the Foreign Trade of the U nited Kingdom since 1856, with Especial Reference to the Effects Produced U pon it by the Protectionist Tariffs of Other Countries," J ournal of the Royal Statistical Society, 41(2)(J une):187-298, p. 200). Greece figures in the "most hostile" group. Thus it is assumed that the protective tariff levels calculated for 1887 had already arrived in 1877, and the years 1869-1876 are interpolated geometrically.

Rider notes that India affected a "departure from free trade" in 1894 with the imposition of a " 5 percent ad valorem duty on all imports except cotton goods and a list of raw materials and machinery used in major Indian industries." With a few modifications, including a change that removed the cotton exemption, this arrangement survived "until the war" (Thomas Rider, 1970, "The Tariff Policy of the Government of India and Industrial Development," J ournal of E conomic History, 30(1)(M arch): p. 278).

Imports and import duties for Indonesia can be found in Korthals A Ites, W. L., 1991, Changing Economy in Indonesia: Volume 12a, General Trade Statistics 1822-1940, Royal Tropical Institute, A msterdam, p. 44-45, 50-54, and 185-187.

Between 1866 and 1895 the "unequal treaties" limited J apanese import tariffs to $5 \%$ ad valorem (William W. Lockwood, 1968, The Economic D evelopment of J apan: Growth and Structural Change, Expanded Edition, Princeton U niversity Press, Princeton, N ew Jersey, 
pp. 18-19). Customs duties for 1893-1894 from ibid. (p. 523) together with imports figures for those years from Banks op. cit. (converted to $Y$ en via factors from Taylor op. cit.) are used to benchmark this period. In $1899 \mathrm{~J}$ apan regained tariff autonomy, but "[e]ven the recovery of tariff autonomy in the nineties still left treaty restrictions on the duties applying to many items. Rates were generally no higher than 10 to $15 \%$ until the general tariff revision of 1911" (Lockwood, p. 539). Following this revision, "[i]n 1914 the ratio of customs revenue to the value of dutiable imports was just under 20 percent" (G. C. Allen, 1981, A Short E conomic History of M odern Japan, 4th ed., St. M artin's Press, N ew Y ork, p. 133).

For M exico, import duties for 1886-1891 come from A ntonio Peñafiel, 1892, Boletín Semestral de la Dirección General de Estadística de la República M exicana, M inisterio de Fomento, M exico City, p. 154. Imports from this same period come from Banks op. cit., converted to pesos using Taylor op. cit. Import duties and imports for 1894-1910 come from the Boletín de Estadística Fiscal, Palacio N acional, M exico City, pp. 63, 139, 146-7, and 173, except 1) imports 1894-96 which come from Banks op. cit. converted as before with Taylor op. cit. and 2) the assumption that on 1906-1910, the fraction of total customs revenue represented by import duties was equal to the average of what that fraction had been during 1894-1906. Tariffs during 1892-1893 are assumed to equal 1894 levels, since Porfirio Díaz reformed the tariffs in 1891 and we thus cannot assume continuity from 1891 to 1892 (Graciela M árquez, 1998, "Tariff Protection in M exico, 1892-1909: Ad V alorem Tariff Rates and Sources of Variation," in John H. Coatsworth and Alan M. Taylor, eds., Latin America and the World E conomy since 1800, Harvard U niversity Press, Cambridge, M assachusetts, $p$. 435). A benchmark for import duties in 1871 is found in Exposición que el Ejectutivo Federal Dirige al Congreso de la U nión, Dando Cuenta del U so que Ha Hecho de las Facultades que le Concedio el Artículo 30 de la Ley de 10 Diciembre de 1871, y del Estado que Guarda la Hacienda Federal en 10 de Abril de 1872, Imprenta del Gobierno, en Palacio, M excio City, 1872, p. 458. This is combined with imports from Banks op. cit. converted via Taylor op. cit. Figures from 1872-1885 are interpolated geometrically, guided by the 1844, 1865, and 1872 benchmarks for import duties given in W alter Flavius M cCaleb, 1921, The Public Finances of M exico, Harper \& Brothers Publishers, New Y ork, pp. 89, 121-2, and 134.

Tariff rates on all imports for $\mathrm{N}$ ew Zealand 1894-1925 are given in J. B. Condliffe, 1959, New Zealand in the Making, 2nd ed., George Allen \& U nwin Ltd., London, p. 250. The source indicates that these figures describe the situation "preceding and following major tariff revisions," suggesting the acceptability of backwards extrapolation to 1870.

Primary sources for Peru 1866-1878 and 1883-1913 are directly quoted in Laura Randall, 1977, A Comparative Economic History of Latin America: 1500-1914. Volume 4: Peru, Institute for L atin A merican Studies, Columbia U niversity, N ew Y ork, pp. 205-6. The period 1879-1882 is interpolated geometrically.

Import duties over imports for the Philippines from 1867-1892 are taken from the Estadística Mercantil del Comercio Exterior de las Islas Filipinas $(1867,1876)$ and the Estadística General del Comercio Exterior de las Islas Filipinas (1881, 1885, 1893). For the periods 1904-1907 and 1912-1914 statistics are available in M CC oy, H. B., 1907, Annual Report of the Bureau of Customs for the Fiscal Year Ending J une 30, 1907, Bureau of Printing, Manila, pp. 50-53 and Foreign Commerce of the Philippine Islands, J anuaryDecember 1914, J uly-D ecember 1913, Bureau of Customs, Department of Finance and 
J ustice, Government of the Philippine Islands, Bureau of Printing, Manila, p. 138. Since protection under the Spanish doubled between 1890 and 1892 (from $7.4 \%$ to $14.7 \%$ ), it is not clear how to fill in the missing years 1893-1903. Since it appears that protection was still rising between 1904 and 1907 (from 20.3\% to 22.4\%), it is assumed that it rose shallowly and slowly on the missing period; that is, the missing years are interpolated geometrically.

Figures for Portugal come from Pedro Lains, 1995, A E conomia Portuguesa no Século XIX: Crescimento E conômico e Comércio Externo 1851-1913, Imprensa N acional, Casa da Moeda, Lisbon, p. 41.

Figures for Russia are in Forrest Capie, 1983, "Tariff Protection and E conomic Performance in the Nineteenth Century," in C. Knick Harley, ed., Integration of the World Economy, Cheltenham, Brookfield, Vermont, pp. 303-4.

A detailed, year-by-year account of Serbian import duties preceding World War 1 is found in Ivan Z. N estorovic, 1913, Der Aussenhandel Serbiens, V erlag von V eit \& Comp., Leipzig, pp. 6-43.

A nnual figures on customs revenue for Spain, nearly all of which was import duties, is in the Estadística de los Presupuestos $\mathrm{G}$ enerales del Estado y de los Resultados que $\mathrm{Ha}$ O frecido su Liquidación, Intervención General de la Administración del Estado, M adrid, p. 69 in the 1850 to $1890-91$ edition, and p. 178 in the 1890-91 to 1907 edition. For the period 1911-1914 the figures can be found in Estadística G eneral del Comercio Exterior de España en 1916, Dirección General de A duanas, Parte Primera, Gráfica Excelsior, M adrid, p. X. This is combined with data on imports from Taylor op. cit. The years 1908-1910 are interpolated geometrically.

Thai customs revenue 1894-1913 and Ticul-denominated imports 1907-1913 are in the Statistical Year Book of the Kingdom of Siam 1917, English edition, Department of Commerce and Statistics, M inistry of Finance, Bangkok, 1917, pp. 36 and 127. Imports for 1894-1906 are taken from Banks op. cit. and converted with Taylor op. cit. Between 1865 and 1890 treaties with all the major powers kept import duties below 3\% (J ames C. Ingram, 1971, Economic Change in Thailand 1850-1970, Stanford U niversity Press, Stanford, California, pp. 34-5). Geometrical interpolation between 1890 and 1894 produces a rapid doubling of tariff rates on this period, consistent with the record that the Thai government began in 1890 to revise the earlier treaties and increase its tariff revenue (ibid., p. 138).

Statistics on import duties for Turkey after 1878 are found in Justin M cCarthy, 1982, The Arab World, Turkey, and The Balkans (1878-1914): A Handbook of Historical Statistics, G. K. Hall \& C 0 ., Boston, pp. 230-1. Stability of the tariff rate during all of 1878-1900 is assumed to hold true during 1870-1877 as well.

Figures for U ruguay, 1882-1911, are in the Anuario Estadístico de la República Oriental del U ruguay 1886, Tipografia Oriental, M ontevideo, 1887 (unnumbered page), and Julio M. Llamas, 1915, Anuario Estadístico de la República Oriental del U ruguay, Años 1911 y 1912, Tipografía M oderna, M ontevideo, pp. 91 and 573. Before 1882 it is assumed that U ruguayan tariff rates mirror those of A rgentina. This is justified because 1) A rgentine and U ruguayan tariff rates were nearly identical during 1882-1890, and U ruguay was under the same military rule during this period as it was during the 1870s, 2) this military government had close ties to the A rgentine government, with which it had fought against Paraguay 1865-1870, and 3) at the onset of civilian rule in U ruguay in 1890, tariff rates spiked upwards. 


\section{Lagged Change in the Terms of Trade}

The regressor is the cumulative change in our best estimate of net barter terms of trade (TOT) during the five years leading up to and including the first year of the period in question.

The index for A rgentina is calculated as an average price of principal exports (beef, hides, wool, grains, linen, tallow) divided by an average price of principal imports (sugar, iron \& steel, liquor \& wine, construction materials, textiles, tobacco, pharmaceuticals, machinery, fuel), where in each case averages are weighted by the share of the total value of each item in the total value of the named principal items. 1870 weights are used for the index during 1870-1891; 1910 weights are used to construct an index on 1889-1913. All figures are taken from various editions of the Anuario del Comercio Exterior, Dirección de Estadistica, Buenos A ires.

Figures for A ustralia during 1870 to 1900 are from W. Vamplew, ed., 1987, Australians: Historical Statistics, Fairfax, Syme \& W eldon, Broadway, N SW, ITFC 81-83, column 83 , p. 194. Figures from 1901-1913 are from Vamplew, op. cit. PC 80-89, columns 87 and 88, p. 220.

Terms of trade for A ustria-H ungary after 1882 are found in Scott M . Eddie, 1977, "The Terms and Patterns of Hungarian Foreign Trade, 1882-1913," J ournal of Economic History, 37(2)(J une):329-358. A $n$ index for 1876-1882 is constructed from indices of the physical quanta and values of exports and imports given in Statistik des Auswärtigen Handels des Österreichisch-U ngarischen Zollgebiets im J ahre 1891, Statistischen Departement im K. K. Handelsministerium, Vienna, 1893, pp. LXVIII-LXIX. For the period 1865-1875 the same source reports only export and import values, not physical quanta. Since the quanta display extremely stable trends during 1876-1892 (unlike the values, which are subject to the vagaries of prices), the quanta for 1865-1875 are extrapolated assuming the same, stable growth rate observed on 1876-1892. Combining these estimates with the trade value figures given for 1865-1875 yield a ToT estimate for this period.

Terms of trade for Brazil for the entire period are calculated in Reinaldo Gonçalves and A mir Coelho Barros, 1982, "Tendências dos termos de troca: a tese de Prebisch e a economia brasileira - 1850/1979," Pesquisa e Planejamento Econômico, Rio de Janeiro, 12(1)(A pril):109-132.

Burmese ToT for 1886-1913 are from M aung Shein, 1964, Burma's Transport and Foreign Trade in Relation to the Economic Development of the Country, 1885-1914, University of Rangoon Press, Rangoon, pp. 223-5, 232-3. During 1865-1885 Burma's ToT are assumed to change at the same rate as those of Thailand.

Figures for Canada come from M.C. U rquhart and K.A.H. Buckley eds., 1965, Historical Statistics of Canada, The U niversity Press, Cambridge. Export price index: Series J, cols. 84 and 108 are linked, pp. 299 and 301. Import price index: Series J, cols. 96 and 118 are linked, pp. 300 and 302.

Ceylon's terms of trade from 1900-1913 are calculated from the export and import price indices in Elaine Gunewardena, 1965, External Trade and the Economic Structure of Ceylon 1900-1955, Central Bank of Ceylon, Colombo, pp. 225 and 227. Figures for before 1900 come from the Ceylon Blue B ook, H.C. Cottle Government Printer, Colonial Secretary's Office, Colombo, 1914. This source gives imports and export values annually 1865-1912, which are converted to current pounds sterling via Taylor op. cit. and to real 
pounds sterling via M cC usker op. cit. These values are used to construct overall export and import price indices through the use of physical quanta indices based on shipping tonnages entered and cleared at port. The source provides separate figures for tonnage entered and cleared for the period 1903-1910, and a combined "entered and cleared" figure for 18651902. Since the separate figures are close to equal for 1903-1910, it is assumed that this holds true during 1865-1902 as well.

Terms of Trade for Chile are constructed as follows. First, an export price index is calculated using copper prices before 1880, and an unweighted average of copper and nitrate prices from 1880 to 1914. Copper prices are from Charles L. K night, 1935, Secular and Cyclical Movements in the Production and Price of Copper, U niversity of Pennsylvania Press, Philadelphia. Although this is an "international" price, its movements on 1871-1887 closely reflect those of a copper price index for $V$ alparaiso found in J oanne F ox Przeworski, 1978, The Decline of the Copper Industry in Chile and the Entrance of North American Capital, 1870-1916, PhD Dissertation, Department of History, W ashington University, Saint L ouis, M issouri. Nitrate prices 1870-1906 are found in E. Semper and M ichels [surname only], 1908, La Industria del Salitre en Chile, M onografía publicada en la Revista Oficial de M inas, M etalurjía i Sustancias Salinas, V ol. 52, 1904, Berlin, traducida directamente del alemán i considerablemente aumentada por Javier Gandarillas M atta i Orlando Ghigliotto Salas, Imprenta Litografía i Encuadernación Barcelona, Santiago, pp. 334-337. Nitrate prices from 1909-1913 are found in James A. F. Brodie, 1915, Nitrate Facts and Figures, $M$ athieson \& Sons, London, p. 7. Second, it is assumed that Chile had the same import price index as A rgentina from 1885-1913, and the same as U ruguay from 1865-1884-an assumption justified by the close correspondence between separately-calculated indices for A rgentine imports, U ruguayan imports, A merican exports, and British exports.

Chinese terms of trade for 1867-1913 are calculated in Y u-K wei Cheng, 1956, Foreign Trade and Industrial D evelopment of China: An Historical and Integrated Analysis through 1948, The U niversity Press, Washington. The figures are reprinted in J ohn K. Fairbank and $\mathrm{K}$ wang-Ching Liu, 1980, The Cambridge History of China, V ol. II, Cambridge University Press, New Y ork, pp. 46-7.

Terms of trade for Colombia are calculated in José A ntonio Ocampo, 1984, Colombia y la Economia Mundial: 1830-1910, Siglo V eintiuno Editores, Bogota, pp. 95-6. Although Ocampo's figures are used, a separate calculation is performed to check them. A $n$ extremely similar ToT index can be obtained by dividing an export index that is the unweighted average of coffee prices (from Taylor op. cit.) and banana prices (from D. W. Rodríguez, 1955, Bananas: An Outline of the Economic History of Production and Trade with Special Relevance to J amaica, The Government Printer, Kingston) by the import price index of Uruguay.

Terms of Trade for Cuba are approximated by dividing an export price index by an import price index. The index of export prices is estimated as an unweighted average of sugar and tobacco price indices. International sugar prices are taken from Taylor op. cit. The assumption that an international sugar price index applies to Cuban exports is supported by Jergen Pedersen and O. Strange Petersen, 1938, An Analysis of Price Behaviour, Institute of Economics and History, Copenhagen, p. 99, which demonstrates how sugar prices in the British W est Indies, Bengal, and J ava followed each other closely throughout the period in question; that is, there is evidence for the existence of a single world price for sugar at the time. A $n$ index of tobacco export prices is taken from $U$ itgave van den Dienst der 
Belastingen in N ederlandsch-Indië, 1925, Tabak: Tabakscultur en Tabaksproducten van Nederlandsch-Indië, Landsdrukkerij-W eltevreden. A gain, why take a Dutch East Indies export price as a proxy for Cuban tobacco export prices? First of all, Cuba in the 1920s was exporting one sixth as much tobacco as the Dutch East Indies and one tenth as much as the United States. That is, Cuba was a price-taker in world markets relative to exporters like the Dutch East Indies (T. L. Hughes, 1925, International Trade in Leaf and M anufactured Tobacco, Trade Promotion Series N 0. 7, Dept. of Commerce, Government Printing Office, Washington D.C., p. 2). Second, we have anecdotal evidence that the prices of tobacco imported from Cuba and from the Dutch East Indies moved together in prewar Europe. When prices for Sumatran tobacco in Germany fell by half between 1907 and 1910, prices for Havana tobacco declined by nearly the same percentage (Jacob W olf, 1922, Der Tabak und die Tabakfabrikate, Verlag von Bernh. Friedr. Voigt, Leipzig, p.130). A n index of import prices for U ruguay is assumed to hold for Cuba as well, justified by the close correspondence of similar import price indices throughout $L$ atin A merica, and moreover the close correlation between these indices and export price indices for the $U$ nited States and Britain during this period.

For Denmark 1870-1875, ToT come from H.C. Johansen, 1985, Danmarks Historie Bind 9: Dansk Økonomisk Statistik 1814-1980, Gyldendalske Boghandel, Copenhagen, Table 4.7, col. 5, p. 217. This is linked with figures from 1875-1913 in N iels Kaergard 1991, $\emptyset$ konomisk Vaekst: En $\varnothing$ konometrisk Analyse af Danmark 1870-1981, Jurist-og Økonomforbundets Forlag, Copenhagen, cols. 2 and 3, p. 578.

Figures for Egypt 1885-1913 come from B. Hansen and E. F. Lucas, 1978, "Egyptian Foreign Trade, 1885-1961: A N ew Set of Trade Indices," J ournal of European Economic History, 7(2 and 3)(Fall/W inter): 429-60, Tables $1 \mathrm{la}$ and $1 \mathrm{~b}$. Export and import indices are calculated as a Fisher index of price over a Fisher index of quantity. B efore 1885 the ToT are assumed to change as do those of the rest of the Ottoman Empire (T urkey).

Terms of Trade for F rance 1870-1896 come from Charles Kindleberger, 1956, The Terms of Trade: A European Case Study, M IT Technology Press, Cambridge, Table 2-1, pp. 12-13. This is linked to a series from 1896-1913 found in P. Villa, 1993, Une Analyse Macroéconomique de la France au XXeme Siècle, CNRS Editions, M onographies d'Économetrie, Paris, pp. 445-6.

German ToT for the entire period come from Walther G. Hoffmann, 1965, Wachstum der Deutschen Wirtschaft seit der M itte des 19 J ahrhunderts, Springer-Verlag, Berlin, Table 134, col. 1, p. 548.

Changes in the ToT for Greece between 1887 and 1899 are obtained by calculating a total value-weighted index of the unit-value of exports (wine, dried fruit and olive oil) and imports (grains and textiles) found in Commerce de la G rèce avec les Pays Étrangers pendant I'Année 1900, M inistère des Finances, Bureau de Statistique, A thens. 1901. Both before 1887 and after 1899, the export price index is linked to an index of dried fruit prices found in J osé M orilla Critz, A lan L. Olmstead and Paul W. Rhode, 2000, "International Competition and the Development of the Dried-F ruit Industry, 1880-1930," in Sevket Pamuk and J effrey G. Williamson, eds., The Mediterranean Response to G lobalization before 1950, Routledge, $\mathrm{N}$ ew $\mathrm{Y}$ ork. The import price index outside the period 1887-1899 is linked to an index of the prices of European manufactured exports found on page 75 of Charles P. Kindleberger, 1958, "The Terms of Trade and Economic Development," Review of Economics and Statistics, 40(1)(F ebruary):72-85. 
Terms of trade for India are taken from B.M. B hattle, 1969, "Terms of Trade and Economic Development: A Case Study of India," Indian Economic J ournal, 16:417-419.

For Indonesia, TOT are calculated by dividing the export and import price indices given by W. L. Korthals A Ites, 1994, Changing Economy in Indonesia: Volume 15, Prices (Non-Rice) 1814-1940, Royal Tropical Institute, A msterdam, pp. 159-160.

Italy's terms of trade with Great Britain are taken as a proxy for overall Italian terms of trade. The former are found in I. A. Glazier, V. N. Bandera, and R. B. Berner, 1975, "Terms of Trade between Italy and the U nited Kingdom 1815-1913," J ournal of European Economic History, 4(1)(Spring): 5-48.

Japanese ToT come from K azushi Ohkawa, M iyohei Shinohara, and M ataji U memura, eds., 1967, Estimates of Long-Term Economic Statistics of J apan Since 1868, V ol. 8, Toyo Keizai Shinpo Sha, Tokyo, Table 18, col. 3, p. 212.

M exican ToT are estimated in the appendix of L aura Randall, 1977, A Comparative E conomic History of Latin America 1500-1914, V ol. 1, Institute of Latin A merican Studies, Columbia University, New Y ork.

$\mathrm{N}$ ew Zealand's terms of trade are given in C. G. F. Simkin, 1951, The Instability of a Dependent E conomy: Economic Fluctuations in New Zealand 1840-1914, Oxford U niversity Press, London, p. 37.

N orwegian ToT are calculated from a total value-weighted price index for principal exports (salted fish, animal skins, timber, and paper products) and imports (meats, grains, sugar, coffee, textiles, coal, salt, and sailing vessels) using numbers on value and physical volume from Central Statistics Bureau of N orway, Historical Statistics 1978, Oslo, pp. 2623, 279-82, 305-9.

Peruvian ToT 1860-1900 are calculated in Shane Hunt, 1973, Growth and Guano in Nineteenth Century Peru, Discussion Paper 34, Research Program in E conomic Development, W oodrow W ilson School, Princeton U niversity, p. 42. Numbers for post-1900 are taken from the appendix of Randall op. cit. Vol. 1.

Terms of trade for the Philippines 1865-1897 are estimated by dividing an export price index by an import price index, where the export price index is calculated as the value of exports over total shipping tonnage clearing port and the import price index is calculated as the value of imports over total shipping tonnage entering port. All numbers are from Benito J. Legarda, Jr., 1999, After the Galleons: Foreign Trade, Economic Change, \& Entrepreneurship in the Nineteenth-Century Philippines, M onograph No. 18, Center for Southeast A sian Studies, University of W isconsin-M adison, pp. 108-9, 112-3. Terms of trade during A merican rule, specifically 1902-1913, are from Thomas B. Birnberg and Stephen A. Resnick, 1975, Colonial Development: An Econometric Study, Economic Growth Center, Y ale U niversity, Y ale U niversity Press, N ew Haven, p. 306.

Portuguese ToT are given in Lains 1995 op. cit., pp. 237-8.

Russian terms of trade for 1856, 1881, and 1894 are calculated from an index of export prices (grains, textiles, oil seed, wool, and naphtha) and import prices (tea, coffee, cotton, copper, iron, zinc, wool, silk, jute, and wax), weighted by total value, from W. J. Kowalewski and E. Davidson, 1898, D ie Produktivkräfte Russlands, Zusammengestellt im Kaiserl. Russischen Finanzmisisterium, Verlag von Otto Wigand, L eipzig, pp. 537-8, 543-4. A fter 1894 the export price index is approximated by an index of Odessa wheat prices (linked to Liverpool prices after 1906) from C. K nick Harley, 1980, "Transportation, the W orld Wheat Trade, and the Kuznets Cycle, 1850-1913," Explorations in Economic History, 
17:218-250. This is justified by the observation that wheat represented almost half of all Russian export value in 1910 ( $M$ argaret M iller, 1967, The E conomic D evelopment of Russia 1905-1915, Frank Cass \& C o. Ltd., N ew Y ork, p. 42). M iller op. cit. also shows that coal and herrings made up nearly half of Russian imports in 1910, so the import price index after 1894 is estimated as an average of coal and herring prices weighted by their relative value shares in imports in 1910. Coal prices come from Pierre Boca, 1937, Salaires et Prix du Charbon dans le Bassin Houiller Rhenan-Westphalien, 1850-1913, Les Editions DomatM ontchrestien, Paris, p. 47. Herring prices are taken to be the unit-value of herring exports from N orway in Central Statistics Bureau of N orway op. cit.

A total value-weighted index of Serbian export prices (pigs, cattle, grains) after 1878 comes from Holm Sundhaussen, 1989, Historiche Statistik Serbiens 1834-1914, R.

Oldenbourg V erlag, M unich, p. 361. The import price index is taken to be the index of European export prices faced by Serbia, 1850-1910, given by Sundhaussen op. cit. p. 336. Export prices are assumed to have remained stable 1865-1878.

Spanish ToT are from Leandro Prados de la Escosura, 1988, De imperio a nación: Crecimiento y atraso económico en España 1780-1930, Alianza Editorial, M adrid, pp. 257-9.

Sweden's terms of trade are taken from Simon Kuznets, 1996 [originally published 1967], "Quantitative A spects of the Economic Growth of N ations: X. Level and Structure of Foreign Trade: L ong-Term Trends," reprinted in C. Knick Harley, ed. The integration of the world economy, 1850-1914, V olume 1, Elgar Reference Collection: Growth of the World E conomy Series, Vol. 3. Cheltenham, U.K, Table 12, p. 150.

A $n$ index of rice prices is assumed to adequately represent an export price index for Thailand, and import prices are approximated as the grey shirting (textiles) price. Their ratio approximates Thai terms of trade. All numbers are from Sompop M anarungsan, 1989, E conomic Development of Thailand, 1850-1950, IA S M onograph N o. 42, Institute of A sian Studies, Chulalongkorn University, Bangkok, Table A 4, pp. 215-6.

Terms of trade for Turkey are calculated in Sevket Pamuk, 1978, Foreign Trade, F oreign Capital and the Peripheralization of the Ottoman Empire, 1830-1913, PhD Dissertation, Dept. of Economics, University of California, Berkeley, California, pp. 279281.

U nited States T OT are from J effrey G. Williamson, 1964, American Growth and the Balance of Payments 1820-1913, U niversity of N orth Carolina Press, Chapel Hill, North Carolina, Table B4, p. 262.

Export and import price indices for U ruguay were kindly provided by Luís Bertola, and ToT are approximated as their ratio.

\section{Transportation Costs}

The regressor is the product of two quantities. The first is the shipping distance, in thousands of nautical miles, from L ondon to the principal port of the destination country that is closest to London. These are taken from the pre-Panama Canal port-to-port distances for full-powered steam vessels recorded in George Philip, ed., 1914, Philip's M ercantile M arine Atlas, 4th ed., The L ondon Geographical Institute, London, endsheet table. The second quantity is an index of tramp shipping freight charges (per distance and weight) shown in Table VIII (p. 122) of L. Isserlis, 1938, "Tramp Shipping Cargoes, and F reights," J ournal 
of the Royal Statistical Society, 101(1):53-146, where the year $1869=1.00$ (i.e. Isserlis' figures have been divided by 100).

\section{Population Growth Rate}

The regressor is the year-on-year percent change in population during the first year of the relevant period. See the aforementioned sources for population data.

\section{Net I mmigration}

The regressor is an average, over the period in question, of an annual index taking an integer value between -3 and +3 . The value +3 signifies large net immigration during that year and -3 signifies large net emigration. Index numbers are constructed for each country in each of five periods: 1865-69, 1870-79, 1880-89, 1890-99, and 1900-14, and assumed to hold in each year of these five periods for the purposes of constructing an average value for our periods I-VI.

Information used to construct the indices for A rgentina, A ustria-H ungary, Brazil, Canada, Chile, Cuba, Denmark, France, Germany, Italy, Norway, Portugal, Spain, Sweden, the U nited States, and U ruguay comes from T. J. Hatton and J. G. Williamson, 1998, The Age of Mass M igration, Oxford U niversity Press, N ew Y ork, p. 10, which draws heavily on I. Ferenczi and W. F. Willcox, 1929/1931, International M igrations, National Bureau of Economic Research, New Y ork, V ol. I 1929 and V ol. II 1931. Chile and U ruguay are assumed to behave similarly to A rgentina.

Figures for A ustralia are estimated based on A. Timmer and J. G. Williamson, 1996, "Racism, X enophobia or M arkets?" Working Paper 5867, National Bureau of Economic Research, A ppendix A, and A. M. Taylor and J. G. Williamson, 1997, "Convergence in the A ge of M ass M igration," European Review of Economic History, 1(1)(A pril): 27-63, Table 1. Based on Ferenczi and Willcox op. cit., migration $\mathrm{N}$ ew Zealand is assumed to behave similarly to that of A ustralia.

M igration data for Egypt, Greece, Serbia and Turkey are from Williamson 2000, "Real wages and relative factor prices around the M editerranean, 1500-1940," op. cit., pp. 64-6, supplemented by the appendix of J effrey G. Williamson, 1998, "Real W ages and Relative Factor Prices in the Third World 1820-1940: The M editerranean Basin," Discussion Paper 1842, Harvard Institute for E conomic Research, Harvard U niversity, Cambridge, M ass.

Documentation for migration flows in China, India, and Japan is relatively poor. It is common knowledge, however, that M adras, other eastern parts of India, and South China were important "labor surplus" or low-wage areas which supplied huge labor supplies to highwage, labor-scarce areas like Ceylon, Burma, Thailand and the rest of Southeast A sia. For example, see the evidence presented in W. A. Lewis, 1969, Aspects of Tropical Development, Wiksell, U ppsala; W. A. Lewis, 1978, Growth and Fluctuations 1870-1913, Allen and Unwin, Cambridge, Mass.; and/or W. A. Lewis, 1978, The Evolution of the International Economic Order, Princeton U niversity Press, Princeton, $\mathrm{N}$ ew Jersey. It is also true, however, that the population from whence the Chinese and Indian emigrants were exiting was itself immense. Thus, while the immigration rates into Burma and Thailand were very large (since the denominators were small), the emigration rates were hardly noticeable 
for the sending areas (since the denominators were huge). It is also well known that J apan never played a significant role in foreign migrations in either direction during the pre-1914 years (although Korean immigration during the World Wars and interwar was significant, as was 20th century J apanese emigrations to Hawaii and the US W est Coast).

Estimates for Burma, Ceylon, Indonesia and Thailand are based on Lewis 1978 op. cit. p. 185. Further information on Burma is found in Teruko Saito and Lee Kin Kiong, 1999, Statistics on the Burmese Economy, Institute of Southeast A sian Studies, Singapore, Table I-2, p. 9. Further information on Thailand is in M anarungsan op. cit. Table. 1.3, p. 34. Low migration levels estimated for Colombia, M exico, and Peru are based on the scant discussion of those countries in Ferenczi and Willcox op. cit. esp. pp. 581-90. Estimates for the Philippines are made based on aforementioned information about the suppliers of their immigrants, especially China and Indonesia, with some assistance from Daniel F. Doeppers and Peter X enos, 1998, Population and H istory: The Demographic Origins of the Modern Philippines, Center for Southeast-A sian Studies, University of Wisconsin, M adison, Wisconsin.

Estimates for Russia are based on Ferenczi and Willcox op. cit. vol. 2, pp. 521-80. Estimates for Cuba are based on Blanca Sánchez A lonso, 1995, Las causas de la emigración española 1880-1930, A lianza Universidad, M adrid, A pendice Cuadro A 3.1, p. 281.

\section{Fraction of Exports B ased on Primary Products}

The regressor is the fraction of total export value, in the first year of the period in question, represented by exports of "primary products" (defined below). This number was made popular as an indicator of the relative abundance of natural resources of all types by J effrey D. Sachs and A ndrew M. Warner, 1995, "N atural Resource A bundance and Economic Growth," Working Paper N 0. 5398, The National Bureau of Economic Research, Cambridge, M ass.

Sachs and W arner defined "primary products" as those commodities falling into categories $0,1,2,3,4$, and 68 of the $U$ nited $N$ ations Standard International Trade Classification (SITC) Revision 1. These categories are, respectively, "food and live animals," "beverages and tobacco," "crude materials excluding fuels," "mineral fuels," "animal or vegetable oils and fats," and "non-ferrous metals." This study uses a slightly different definition of primary products, namely categories I, II, and III of the Brussels 1913 Commodity Classification (recorded in Conference Internationale de Statistique

Commerciale, Bruxelles, 1913: D ocuments et Procès-Verbaux, É stablissements Généraux D'Imprimerie, Brussels, 1914). These categories are, respectively, "live animals," "food and drink," and "raw materials or simply-prepared products." That is, our definition of "primary products" includes all exports except categories IV ("manufactured products") and $V$ (money and specie). The only substantive differences between our definition of "primary product" and that based on the SITC are that the former includes iron ore and excludes manufactured tobacco products like cigarettes and cigars.

Figures for the U nited States, France, Germany, Russia, A ustralia, A ustria-H ungary, Italy, Japan, Spain, Sweden, and Chile are from L eague of N ations, 1945, Industrialization and Foreign Trade, Economic, Financial and Transit A uthority, Geneva, pp. 157-9. An additional benchmark for Spain is available in Estadística General del Comercio Exterior de Espana 1862, Dirección General de A duanas, M adrid, pp. xxxvii and xxxix. 
The L eague of Nations data for A ustria-H ungary, which only go back to 1881, are extended back to 1865 by numbers from Statistik des Auswärtigen $\mathrm{H}$ andels des Österreichisch-U ngarischen Zollgebiets im J ahre 1891, Statistischen Departement im K. K. $\mathrm{H}$ andelsministerium, Wien, 1893, pp. LXXVI-LXXVII. N ote that manufactured food items had to be removed from "manufactured goods" to make these data fit the Brussels classification.

It is clear that Brazil had no significant exports outside B russels classifications I-III during this period, from figures for 1904-5 in Importação e Exportação: M ovimento Marítimo, Cambial e do Café da República dos Estados U nidos do Brasil em 1905, Serviço de Estatística Commercial, M inistério da Fazenda, Imprensa Nacional, Rio de Janeiro, 1907, pp. 193-5, and figures for 1913-14 in Commercio Exterior do Brasil, Vol. 1, 1910 a 1914, Directoria de Estatística Commercial, M inistério da Fazenda, República dos Estados U nidos do Brasil, Rio de Janeiro, 1915, pp. 21-4.

Figures for India for 1899 and after are found in H. Tyszynski, 1951, "W orld Trade in M anufactured Commodities," The Manchester School of Economic and Social Studies, 19(3)(September): 272-304, on pages 277-8, 299, and 304. It is assumed that the fraction of Indian exports composed of manufactured goods grew at the same year-on-year rate during 1865-1898 as it did during 1899-1913. B urma is assumed to have the same figure as India in each period.

Figures for Canada are found in Canada Bureau of Statistics, 1910, The Canada Year Book, C. H. Parmelee Printer to the King's M ost Excellent M ajesty, Ottawa, pp. 66, 69.

Detailed ledgers of Ceylon's exports in 1904 are found in the 1905 Ceylon Blue Book, pp. U 58-U 87. Figures for 1912 are in the 1912 Ceylon Blue Book, pp. M 44-M 83. Both show that the fraction of exports falling into categories I-III is very close to unity, suggesting that reliable figures for earlier years can be extrapolated.

Figures for China are presented in C. Y ang, H. B. Hau, and others, 1931, Statistics of China's Foreign Trade during the Last Sixty-Five Years, M onograph N o. IV, National Research Institute of Social Sciences, A cademia Sinica, Beiping, p. 27.

Figures for Colombia are in Ocampo 1984, op. cit., pp. 100-1, 391-5.

Cuban figures for 1899-1902 are in Estadística General: Comercio Exterior, Secretaria de $\mathrm{H}$ acienda, República de Cuba, M ayo y J unio de 1902, Havana, p. 17. Figures for 1904-1913 are in Comercio Exterior, Segundo Semestre del Año 1913 y Año de 1913, Sección de Estadística, Secretaria de Hacienda, Republica de Cuba, Havana, 1914, p. 9. The turn-of-the-century figures are assumed to hold throughout the late $19^{\text {th }}$ century.

Data from D enmark 1896-1913 are taken from the export ledgers in Importation et Exportations du Danemark (Danmarks Vareindførsel og -udførsel), Departement de Statistique, Copenhagen, various years. Since the resulting figure of $96 \%$ does not significantly change between 1896 and 1913, it is assumed to hold constant on 1870-1896.

D ata for Egypt 1885-1909 are in the Statistical Yearbook of Egypt for 1909, First Issue, Statistical Department, M inistry of Finance, $\mathrm{N}$ ational Printing Department, Cairo, 1909, pp. 87, 98, 104-5. The figures from the early 80's are assumed to hold back to 1870.

Data on Greek exports 1887-1910 are in Commerce de la Grèce avec les Pays Étrangers pendant l'Année 1900, M inistère des Finances, Bureau de Statistique, A thens. 1901, p. 6. The 1887 figure is assumed to hold constant back to 1870.

Data on Indonesia for 1865-1913 are in W. L. Korthals A Ites, 1991, Changing Economy in Indonesia: Volume 12a, General Trade Statistics 1822-1940, Royal Tropical 
Institute, A msterdam, pp. 141, 144. The graph on page 141 clearly justifies extrapolation of 1865-1873 figures all the way to 1913.

D etailed M exican export composition for $1880-1891$ is found in A ntonio Peñafiel, 1888, Boletín Semestral de la Estadística de la República M exicana, M inisterio de Fomento, M exico, pp. 186-189. That there was no decrease in this figure even right before the $W$ ar is confirmed by figures for 1912-3 in The Mexican Year Book: A Financial and Commercial Handbook, compiled from Official and other Returns, 1914, Dept. of Finance, M exico City, pp. 16-17.

Complete data for $\mathrm{New}$ Zealand are to be found in G. T. Bloomfield, 1984, New Zealand: A Handbook of Historical Statistics, G. K. Hall \& Co., Boston, pp. 271-2.

Complete data for $N$ orwegian export composition are in Central Statistics Bureau of Norway, op. cit., pp. 262-3.

It is assumed that Peru had no exports in Brussels Class IV during this period, since it had developed none by 1918-as can be seen in Extracto Estadístico Correspondiente al Año 1918, Preparado por la Dirección de Estadística del M inisterio de Fomento, Lima, p. 89.

Detailed export ledgers for 1890-4, 1899-1904, and 1906-7 are in M onthly Summary of Commerce of the Philippines Islands, various years, Division of Insular Affairs, War Department, W ashington. Benchmarks for the years 1867 and 1876 are in Estadística Mercantil del Comercio Exterior de las Islas Filipinas, A ño de 1867 [and 1876], M anila.

Portuguese export composition is reported in Lains 1995 op. cit., p. 92.

Figures for Serbia, 1879-1910, are in Nestorovic op. cit. pp. 130, 134, 137, and 139.

Export breakdowns for Thailand 1908-12 are presented in Foreign Trade and Navigation of the Port of Bangkok: Years 129 (1910-11) and 130 (1911-12), Prepared in the Statistical Office, H. S. M. Customs, and Published by Order of the Director-General, Bangkok, pp. 75-83. These ledgers reveal that manufactures in 1908 were less than $1 \%$ of export value, suggesting that reliable figures can be obtained from extrapolation back to 1870.

Full data for Turkey are presented in Pamuk 1978 op. cit., pp. 235-249, and confirmed in Sevket Pamuk, 1995, 19. Yuzyilda Osmanli Ticareti (Ottoman Trade in the $19^{\text {th }}$ Century), T.C. Basbakanlik D evlet Istatistik Enstitusu (State Institute of Statistics, Prime M inistry), A nkara, p. 36.

Detailed ledgers of U ruguayan export composition are given in Anuario de Estadística de la República O riental del U ruguay, Dirección de Estadística General, M ontevideo, years 1884, 1895, and 1911-12.

Data for A rgentina come from Randall op. cit. V ol. 2, pp. 218-9.

\section{Primary Product Based Exports as a F raction of GDP}

The above index of the fraction of exports based on primary products is multiplied by total export value and divided by total GDP to obtain the value of primary product-based exports as a fraction of GDP, an alternative indicator of natural resource abundance used in Sachs and Warner op. cit. Figures for GDP are obtained by multiplying the above estimates of GDP per capita by estimates of population. Export figures for A rgentina, A ustralia after 1900, A ustria-H ungary, Brazil, Canada, Chile, China, Colombia, Cuba after 1902, Denmark, France, Germany, Greece, Italy, Japan, M exico, Norway, Peru, Portugal, Russia, Spain, Sweden, Thailand, Turkey, the U nited States, and U ruguay come from Banks op. cit. 
Those for A ustralia before 1900, Ceylon, Cuba before 1902, Egypt, India, Indonesia, N ew Zealand, Philippines, and Serbia come from A rthur Lewis, 1981, "The Rate of Growth of World Trade, 1830-1973," in Sven Grassman and Erik Lundberg, eds., The World E conomic Order: Past and Prospects, St. M artin's Press, N ew Y ork.

Burmese exports for 1913 come from Statistical Abstract for British India, Government of Calcutta, India Publication Branch, Commercial Intelligence D epartment, 1914. Burmese exports from 1902-1912 are from Statistics of B ritish India, Part II: Commercial, Director-General of Commercial Intelligence, Calcutta, 1913. Burmese exports for 1874-1902 are from Statistical Abstract Relating to British India, V arious Y ears, Eyre \& Spottiswoode for HM SO, Presented to both Houses of Parliament by Command of $\mathrm{Her}$ M ajesty, London. All export figures are converted into real, 1990 US dollars via M cC usker op. cit.

\section{Land Area}

L and areas are in square miles and correspond to country borders as defined in the first section of this appendix.

A reas for A rgentina, A ustralia, A ustria-H ungary, Brazil, Canada, Chile, China, Colombia, Cuba, Denmark, France, Germany, Greece, Italy, Japan, M exico, N ew Zealand, N orway, Peru, Portugal, Russia, Serbia, Spain, Sweden, Thailand, Turkey, the U nited States, and U ruguay come from Banks op. cit.

A reas for Burma, Ceylon, Egypt, India (sum of modern India, Pakistan, and Bangladesh), Indonesia, and the Philippines come from the Encyclopedia Britannica.

\section{U rbanization}

This regressor is the fraction of the population living in urban agglomerations of 100,000 or more in the first year of the period in question.

Data for A rgentina, A ustria-H ungary, Brazil, Canada, Chile, Colombia, Denmark, France, Germany, Greece, Italy, Japan, M exico, N orway, Peru, Portugal, Russia, Serbia, Spain, Sweden, Turkey, the U nited States, and U ruguay come from Banks op. cit.

Data for A ustralia, Ceylon, Cuba, Egypt, India, the Philippines, and Thailand are in the appropriate volume of M itchell 1998 op. cit. A $n$ additional benchmark for India is in Edwin S. M ills and Charles M. Becker, 1986, Studies in Indian U rban Development, The World Bank, Oxford U niversity Press, N ew Y ork, p. 34. A n additional benchmark for the Philippines is in Rajeswary A mpalavanar Brown, 1994, Capital and Entrepreneurship in South-E ast Asia, St. M artin's Press, N ew Y ork, p. 228.

Figures for Burma are in Saito and Kiong op. cit., p. 16.

Data for China come from Kang Chao, 1986, M an and Land in Chinese History: An Economic Analysis. Stanford U niversity Press, Palo Alto, California. N ote that Chao defines an urban agglomeration as consisting of only 2,000 people, so this number can be best considered an upper-bound proxy. Since it is low in all years, the error introduced by overestimation cannot be large.

Figures for Indonesia are in P. Boomgaard and A . J. Gooszen, 1991, Changing Economy in Indonesia: Volume 11, Population Trends 1795-1942, Royal Tropical Institute, A msterdam, pp. 213, 220. 
Data for N ew Zealand are in G. T. Bloomfield, 1984, New Zealand: A Handbook of Historical Statistics, G. K. Hall \& Co., Boston, p. 56.

\section{School E nrollment}

This regressor is the fraction of the population aged 14 years or less that is enrolled in primary school in the first year of the period in question, and is in units of enrolled students per 10,000 persons aged 14 years or below. It is calculated as the quotient of 1) primary enrollment as a fraction of the total population and 2) children aged 14 or below as a fraction of the total population. Each is discussed in turn.

Enrollment as a fraction of total population: Data for A rgentina, A ustralia, Brazil, Burma, Ceylon, China, Egypt, France, Germany, India, Indonesia, Italy, Japan, M exico, the Philippines, Russia, Serbia, Spain, Thailand, Turkey, and the U nited States are from Richard A. Easterlin, 1981, "W hy Isn't the Whole W orld Developed?" J ournal of E conomic History, 41(1)(M arch):1-19., and Richard A. Easterlin, 1996, Growth Triumphant, U niversity of M ichigan Press, A nn A rbor, p. 61. Data for A ustralia, A ustria-H ungary, Canada, Chile, Colombia, Denmark, Greece, N orway, Peru, Portugal, Sweden, and U ruguay are from Banks op. cit. Data for Ceylon are from the 1914 edition of the Ceylon Blue B ook, endsheet. A dditional data for Colombia are in 1869, 1870, and 1883 are found in Ocampo 1997 op. cit., p. 160-1 and Gabriel Poveda Ramos, 1979, Dos Siglos de Historia Económica de Antioquia, Biblioteca Pro A ntioquia, Medellin, p. 95. Additional data for $\mathrm{Cuba}$ are in Susan Schroeder, 1983, Cuba: A Handbook of Historical Statistics, G. K. Hall \& Co., Boston. A dditional data for $\mathrm{N}$ ew Zealand are in Bloomfield op. cit., p.110.

Children aged 14 or below as a fraction of the total population (the "youth dependency ratio"): Data for A rgentina, A ustralia, A ustria-H ungary, Brazil, Burma, Canada, D enmark, France, Germany, Greece, India, Italy, Japan, M exico, N orway, Portugal, Russia, Spain, Sweden, and the U nited States come from the appropriate volume of $M$ itchell 1998 op. cit. Figures for Chile are from M amalakis op. cit. volume 2. Figures for Ceylon are approximated using a straightforward demographic model employing population growth figures from the 1914 Ceylon Blue Book, and viable birth and infant mortality statistics from L. J. B. Turner, 1923, Report on the Census of Ceylon 1921, H. Ross Cottle, Government Printer, Ceylon, pp. 11, 15.

$\mathrm{Y}$ outh dependency ratio statistics for $\mathrm{C}$ hina are gathered from a range of sources, giving a picture of trends in the ratio from 1771 to 1990. Data for 1771-1835 and 1872 are from Ping-ti Ho, 1959, Studies on the Population of China 1368-1953, Harvard U niversity Press, Cambridge, M ass., pp. 59, 68. A benchmark from 1842 is in Gilbert Rozman, 1982, Population and Marketing Settlements in Ch'ing China, Cambridge University Press, 1982, p. 59. A figure from 1953 is in S. Chandrasekhar, 1960, China's Population: Census and Vital Statistics, Hong Kong U niversity Press, Hong Kong, p. 47, and figures from 1953, 1964, and 1982 are in Li Chengrui, 1992, A Study of China's Population, Foreign Languages Press, Beijing. A datapoint for 1958 is in Chai Sunglin, 1977, Population and Population Policy in Mainland China, A sia and the World Forum, Monograph 6, Taipei, Taiwan, p. 56. Benchmarks for 1926, 1929, 1931, 1934, and 1947 are in Y ang Zi Hui, 1995, China $\mathrm{H}$ istorical Population Data and the Relevant Studies, China R eform Publishing House, Beijing, pp. 1364, 1366, 1369. The general agreement of these disparate figures on longterm trends in the population structure allows confident interpolation for 1870-1913. 
Data for Colombia come from M itchell op. cit. 1998, Ocampo 1997 op. cit. p. 160, and Poveda op. cit. p. 95. Data for Cuba are from Schroeder, op. cit., pp. 51-3. A benchmark for Egypt in 1917 is from M itchell 1998 op. cit., and in preceding years the Egyptian youth dependency ratio is assumed to change at the same rate as that of India. Data for Indonesia are from Boomgaard and Gooszen, op. cit. pp. 200-3. Figures for $\mathrm{New}$ Zealand are in Bloomfield op. cit., pp. 48-50. Peruvian figures for 1876 are benchmarked in Alida Díaz, 1974, El Censo General de 1876 en el Perú, Seminario de Historia Rural A ndina, Lima, Table 8, page 33. These are compared with post-1940 statistics in M itchell 1998 op. cit. to reveal long-term trends in the Peruvian population structure. For the Philippines, there is a 1918 benchmark in Felipe Buencamino, Sr., 1921, Census of the Philippine Islands, Vol. 2, Census Office of the Philippine Islands, M anila, p. 65, and a 1903 benchmark in J. P. Sanger, 1905, Census of the Philippine Islands, V ol. 2, United States Bureau of the Census 1905, p. 65. Serbian data come from Sundhaussen op. cit. p. 114. Data for Thailand in 1911, 1925, 1947, and 1960 come from the Statistical Year B ook of the Kingdom of Siam published by the M inistry of Finance, and data points for 1929 and 1937 are in M itchell 1998 op. cit. Together these give a clear view of long-term trends in the Thai population structure that allow confident extrapolation to the period 1870-1913. For Turkey, an 1886 benchmark can be found in M cCarthy, op. cit., p. 87, and comparison points for 1935-1960 are in M itchell 1998 op. cit., giving a clear picture of long-term trends in Turkish demographic structure. U ruguayan dependency ratios for 1900 and 1908 are in M itchell 1998 op. cit., and before 1900 they are assumed to have changed at the same rate as did those for A rgentina.

\section{Unskilled, Real, PPP-adjusted, Urban Wages relative to those of G reat B ritain}

This regressor is an index of the unskilled, urban, real, purchasing power-adjusted urban wage in that country in the current year-where the unskilled, urban, real, purchasing power-adjusted urban wage in Great B ritain in the current year corresponds to the index value 100.

Figures for A ustralia, Brazil, Canada, D enmark, France, Germany, Italy, N orway, Portugal, Spain, Sweden, and the U nited States come from J effrey G. Williamson, 1995, "The Evolution of Global Labor M arkets since 1830: Background Evidence and Hypotheses," Explorations in Economic History, 32:141-196.

Figures for Burma, China, India, Indonesia, Japan, the Philippines, and Thailand come from J effrey G. Williamson, 2000, "Globalization, Factor Prices and Living Standards in A sia before 1940," in A. J. H. L atham and Heita Kawakatsu, eds., Asia-Pacific Dynamism 1550-2000, Routledge, N ew Y ork.

Figures for Egypt, Serbia, and Turkey come from J effrey G. Williamson, 2000, "Real Wages and Relative Factor Prices around the M editerranean, 1500-1940," op. cit. It is assumed that the index value for Turkey is a good proxy for that of Greece, due to similarities of economy and geography as well as a high rate of labor mobility between the two.

Figures for A rgentina, Colombia, Cuba, M exico, and U ruguay come from J effrey G. Williamson, 1998, "Real Wages and Relative Factor Prices in the Third W orld 1820-1940: Latin A merica," Discussion Paper 1853, Harvard Institute of Economic Research, Harvard University, Cambridge, M ass. 
A ustro-H ungarian nominal unskilled urban wages 1891-1913 come from M ichael M esch, 1984, Arbeiter existenz in der Spatgrunderzeit: Gewerkschaften und Lohnentwicklung in Ö sterreich 1890-1914, E uropaverlag, V ienna, p. 287 (unweighted average of the eight cities shown). These are converted to real wages with a price index calculated as the unweighted average of three grain prices given in A Ifred Francis Pribram, 1938, M aterialen zur G eschichte der Preise und Löhne in Österreich, Carl U eberreuters V erlag, V ienna, pp. 371-3. The resulting real wage series is adjusted for purchasing power based on data on A ustrian and British prices for the year 1913 in Wesley C. M itchell, 1919, International Price Comparisons, Government Printing 0 ffice, Washington, pp. 56-154 and 320-328. The British real wage series with which it is compared comes from Williamson 1995 op. cit. The result of extrapolation before 1891 matches well with a relative wage benchmark for the year 1884 in M ichael G. M ulhall, 1885, H istory of Prices since the Year 1850, L ongmans, Green, and $\mathrm{C} 0$., L ondon, p. 125. The resulting series also corresponds to the observation that “...both money wages and real wages probably declined until the mid 1890s. Only after the effect of mass migration had made its impression on the labor market, i.e., after the turn of the century, did wages rise again" (Scott M. Eddie, 1983, "A griculture as a Source of Supply: Conjectures from the History of Hungary, 1870-1913," in John Komlos, ed., Economic Development in the Habsburg Monarchy in the Nineteenth Century: Essays, Columbia University Press, N ew Y ork, p. 111).

Russian real wages come from the unpublished manuscript Russian Economic Growth before 1917 by Robert C. Allen of the U niversity of British Columbia. These are compared to British real wages from Williamson 1995 op. cit. by information on 1913 relative consumer prices in Russia and Great Britain in W esley M itchell, op. cit., pp. 56-154 and 210-225.

It is assumed that the index value for A ustralia is a good proxy for that of $\mathrm{New}$ Zealand. This is justified by economic and geographic similarities, labor mobility, and by a calculation showing that purchasing power-adjusted wages of "builders and general laborers" in N ew Z ealand 1895-1900 were identical to those of their counterparts in A ustralia. For this calculation, N ew Zealand nominal unskilled urban wages came from M. B. Hammond, 1917, "The Regulation of Wages in N ew Zealand," Q uarterly J ournal of Economics, 31(3)(M ay): 404-46. A $\mathrm{n}$ index of $\mathrm{N}$ ew Zealand prices relative to those in Great Britain is found in J. W. M cllraith, 1913, "Price V ariations in N ew Zealand," The Economic J ournal, 23(91)(September):348-354. British nominal unskilled urban wages are on page 310 of A. L. Bowley, 1900, "The Statistics of Wages in the U nited Kingdom during the L ast Hundred Y ears. (Part IV) The Building Trades, English Towns," J ournal of the Royal Statistical Society, 63(2)(June): 297-315. Lastly, a British real wage index is found in J effrey G. Williamson, 1995, "The Evolution of Global L abor M arkets since 1830: Background Evidence and Hypotheses," op. cit.

For all other regressors we have complete data for all countries in all periods; for wages, however, we have no data for Ceylon, Chile, and Peru. For Cuba, we only have data for period VI. All other countries and periods are complete. 